\title{
A KÖZÉPKORI ÉPÍTÉSZET SZERKESZTÉSI MÓDSZEREI A HAZAI SZAKIRODALOM TÜKRÉBEN
}

\author{
FEHÉR KRISZTINA* - HALMOS BALÁZS** \\ *Tudományos segédmunkatárs. BME Építészettörténeti és Mủemléki Tanszék. 1111 Budapest, \\ Müegyetem rkp. 3. K. II. 83. E-mail: fkristin66@gmail.com \\ **PhD, egyetemi adjunktus. BME Építészettörténeti és Mủemléki Tanszék. 1111 Budapest, \\ Mủegyetem rkp. 3. K. II. 83. Tel.: (+36-1) 463-2302. E-mail: halmos@eptort.bme.hu
}

\begin{abstract}
A műemléki helyreállítások és az építészettörténeti kutatás komoly szakmai körültekintést, a téma több résztudomány szempontjából történő vizsgálatát igényli. A tervezési és előkészítési folyamat nemcsak napjainkban, hanem a történeti korokban is az építészeti alkotás kulcskérdésének tekinthetö, ezért ennek ismerete mind az építészettörténet, mind pedig a müemlékvédelmi tevékenység fontos adalékául szolgál. Tanulmányunk a középkori épületek geometriai, arányossági rendszereinek, tervezési, szerkesztési módszereinek összefoglalására és kronologikus rendben történő bemutatására vállalkozik a hazai szakirodalom alapján.

Ennek a témának magyarországi kutatástörténete - a nemzetközi szakirodalommal összhangban - a 19. század közepére nyúlik vissza. Ez alatt a több mint másfél évszázad alatt az építészettörténeti kérdésekben releváns tudományok - építészet, művészettörténet, régészet, szobrászat - képviselői eltérő, de egytől egyig elöremutató nézőpontokkal gazdagítva gyarapították ismereteinket a középkor tervezési, geometriai és arányossági elméletéről. E szerteágazó ismeretanyag összefoglalása és rendszerezése segít feltárni a még megválaszolatlan kérdéseket és világossá teszi a kutatás jövőbeli irányait. Tanulmányunk e tudománytörténeti hagyomány előtt tisztelegve gyüjti össze a középkori szerkesztőmódszerekről szóló kutatómunkákat nem kisebbítve a középkor más részterületeivel vagy akár egészével foglalkozó kutatások jelentőségét.
\end{abstract}

Kulcsszavak: középkor, geometria, arány, szerkesztés, tervezés, Villard de Honnecourt, Roriczer

Tanulmányunk ${ }^{\#}$ a középkori építészet szerkesztési és méretmeghatározó módszereinek magyarországi kutatástörténetét tekinti át az 1850-es évekbeli kezdetektől napjainkig. Átfogóan szemlélve ezt a másfél évszázadot, megállapíthatjuk, hogy a téma irodalma egyre szempontgazdagabban és ezek szintézisével egyre komplexebben közelít a kérdéshez, ezért egyre árnyaltabb képet kapunk a középkori tervezés módszereiről. A szempontok gyarapodása egyre tágabb értelmezési síkra tereli az építést megelőző, előkészítő folyamat vizsgálatát, rámutatva arra, hogy a tervezéselméleti kérdések a középkori építészet kutatásának csaknem minden résztudományával összefüggésbe hozhatók. Kétségtelen azonban, hogy a módszertani változatossággal együtt megválaszolatlan kérdéseink száma is egyre nő. A 19. századi építészet gótizáló tendenciáinak megjelenésekor a kutatás még nélkülözte a körültekintő vizsgálati módszereket, pedig a középkori tervezéselméletre vonatkozó hipotézisek ekkor egyben az alkotó építészet elméleti hátterét is jelentették. Ez a probléma hívta

\#A tanulmány megjelenését az OTKA 112906-os számú pályázata támogatta. 
életre a középkor építészetének tudományos igényü kutatását. ${ }^{1}$ Mára a téma aktualitása a tervezői praxis szempontjából jelentősen csökkent, hasznosítása leginkább a müemlékvédelemre és a helyreállítási munkák megalapozására korlátozódik. Kutatástörténeti összefoglalónk azonban nemcsak az épületkutatásoknál elengedhetetlen hasznosságára hívja fel a figyelmet, hanem arra is, hogy ismeretével közelebb juthatunk a középkori építőkultúra és gondolkodásmód megértéséhez.

\section{KUTATÁSTÖRTÉNETI ÖSSZEFOGLALÓ}

Tanulmányunkban megkíséreljük összefoglalni azoknak a magyar kutatóknak a munkásságát, akiknek múvei a téma hazai szakirodalmát meghatározzák. Bár összefoglalónkban törekszünk a teljességre, e tanulmány keretében nincs lehetőség valamennyi olyan tudományos kutatás bemutatására, mely egy-egy középkori építészeti emlék szerkesztési vagy méretezési módszerét és geometriai formáinak elemzését érintette. Figyelmünket elsősorban azokra a munkákra fordítottuk, melyek az alkalmazott eljárások elméleti hátterével is foglalkoztak, eredményeiket tágabb építészettörténeti összefüggések feltárására igyekeztek felhasználni, vagy akár egyfajta középkori tervezéselméleti szerkesztőrendszer felvázolására tettek kísérletet.

A hazai kutatók közül a témában az első és rendszerében legteljesebb hipotézist Henszlmann Imre (1813-1888) állította fel, amely azonban vitathatósága miatt csekély visszhangra talált. Henszlmann nevét müemlékfeltárásai és helyreállításai kapcsán ismerjük, kevésbé köztudott, hogy szinte egész életmüvét történeti építészeti arányelmélete igazolásának szentelte, és számára még a helyreállítások is ennek bizonyítását szolgálták. ${ }^{2}$ Részletesen kidolgozott elméletének alapja a köbháromszög volt, rendszere a kocka oldalának, lapátlójának és testátlójának egymáshoz viszonyított arányára épült $(1: \sqrt{2}: \sqrt{3})$. Az ezek felhasználásával képzett számsorozat elemeiben vélte felfedezni az építészeti tervezés aránybeli összefüggéseit az ókortól a középkor végéig. A köbháromszög egységnyi hosszúságú rövidebbik befogóját unitasnak (U) nevezte el. Ebből a háromszögből hasonló háromszögeket képzett, majd ezek oldalhosszúságaiból számsorozatot alkotott. Ez jelentette rendszerének alapját. Antik templomok esetében a cella, középkoriak esetében a föhajó szélességét (oszloptengely-távolság) tekintette a méretrend kiindulásának, az unitasnak, amellyel az egész alapszámsorozatot beszorozta. Az épületek összes méretét az így kapott egyedi rendszer elemeivel azonosította, még akkor is, ha ez csak több tizedesjegynyi pontatlanság árán sikerült. Henszlmann hasonló, de az alap köbháromszögben eltérō rendszert dolgozott ki az antik és a középkori épületek arányaira vonatkozóan, ekképpen a két korszak tervezési módszereinek folytonosságát feltételezte (1. ábra).

${ }^{1}$ Zádor 1966. 210-214.

${ }^{2}$ Möller István kéziratos jegyzeteiben rögzítette, mennyire elvakultan ragaszkodott Henszlmann a systhema védelméhez, amelyröl halálos ágyán is megemlékezett. Forster Gyula Nemzeti Örökségvédelmi és Vagyongazdálkodási Központ Kézirattára (a továbbiakban Forster Irattár) K133/2. 


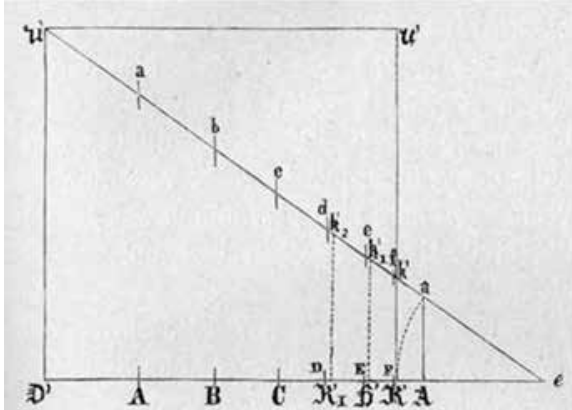

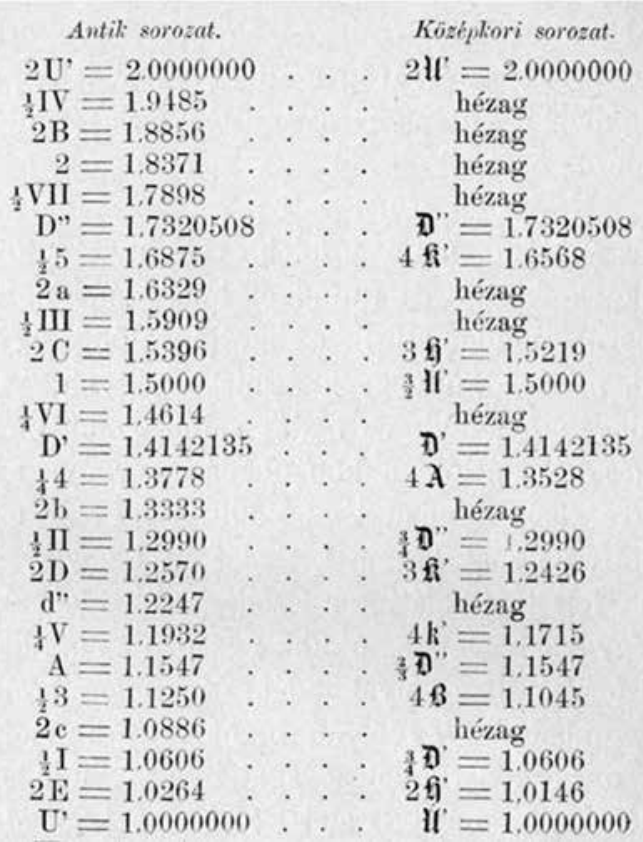

1. ábra. Henszlmann Imre antik és középkori arányelméletének köbháromszög-sorozata, illetve számsorozata (forrás: Henszlmann 1880. 5-7)

Mủveiben az emlékek régészeti és történeti leírása mellett minden esetben külön fejezetet szentelt annak, hogy azokat elméletébe beillessze. ${ }^{3}$ Möller István visszaemlékezései szerint erösebben törekedett az épületek segítségével elméletének igazolására, mint elméletének felhasználására az épületek elemzéséhez. ${ }^{4}$ Henszlmann számára a középkorra vonatkozó arányozási rendszer valóságos építészetelmélet volt, ${ }^{5}$ ugyanis több alkalommal javasolta a helyreállítandó müemlékek átalakítását, hogy sorozatába jobban illeszkedjenek. ${ }^{6}$ Henszlmann eredményeit már kortársai is fenntartásokkal fogadták. Elsősorban azt észrevételezték, hogy a sorozat elemei között

\footnotetext{
${ }^{3}$ Henszlmann 1863, 1864, 1866a, 1866b, 1870, 1873, 1876, 1878, 1880.

${ }^{4}$ Möller István kéziratos jegyzeteiben emlékezett rá, hogy Henszlmann a múemlékeket már nem is mủvészi és történeti értékük alapján ítélte meg, hanem, hogy alkalmasak-e elméletének igazolására. Forster Irattár K133/2.

${ }^{5}$ A 19. század közepén Európa-szerte elterjedt a középkori építészet titkának elméleti kutatása. A 18. századi - főleg Angliában jelentős - preromanika ugyanis a gótika képi (pittoreszk) világát ragadta meg, amelynek eredményével a közönség és az építészek egyre kevésbé voltak elégedettek. A kutatók és a lelkes amatőrök a középkori épületek arányainak megtalálásában látták a gótizálás tökéletesítésének módját, amellyel összefüggésben nagyszabású mủemlékfelmérési mozgalmak indultak. Zádor 1966. 210-214; Levárdy 1969. 197.

${ }^{6}$ Ilyen volt például a bélapátfalvai ciszterci apátság - meg nem valósult - helyreállitási terve. Henszlmann 1866a 77; Gergelyffy 1958. 208-210. Továbbá Möllernek a vajdahunyadi vár helyreállítása kapcsán a középkori terek belmagasságának módosítását javasolta. Forster Irattár K133/2.
} 
olyan csekély különbségek vannak, hogy abba bármilyen adat beilleszthetö, ${ }^{7}$ továbbá azt, hogy az elmélet nem veszi figyelembe a középkori építészet idő- és térbeli eltéréseit, stílusrétegeit, mühelysajátosságait. ${ }^{8}$ Bár elmélete zsákutcának bizonyult, Henszlmann - még ha túl bonyolult úton is - olyan összefüggésekre jött rá, amelyekre később más kutatók középkori források alapján eljutottak, ilyen például az $1: \sqrt{ } 2$, $1: \sqrt{3}$ arány gyakori előfordulása vagy az épület méreteinek és arányainak kevésbé aritmetikai, mint inkább grafikus meghatározása. ${ }^{9}$

Henszlmann kortársa, Myskovszky Viktor (1838-1909) a bártfai Szent Egyedtemplom szentségházának arányait vizsgálva az aranymetszés középkori alkalmazásának bizonyítékát kereste. Kimutatta, hogy a szentségház magassági osztópontjait az aranymetszés arányával jelölték ki. Tudomásunk szerint munkáját ebben a témában nem folytatta, ami talán annak köszönhetö, hogy cikkére Henszlmann rögtön utóirattal válaszolt, amelyben az aranymetszés helyett saját elméletének müködését hangsúlyozta. ${ }^{10}$ Myskovszky mindazonáltal arra hívta fel a figyelmet, hogy az aranymetszés nemcsak a teljes gótikus épületek, hanem a kisebb épületrészek és a legapróbb részletek (tornyok, ablakok, nyíláshevederek stb.) tervezésének is meghatározó szerkesztőmódszere lehetett. ${ }^{11}$

Frőde Vilmos (1847-1920) építész, a kassai Szent Erzsébet-dóm és más felvidéki emlékek restaurátora a magyar szakirodalomban először méltatta Franz Ržiha kőfaragójel-elméletét, amely szerint a mesterjegyek geometrikus alapidomai a négy fó német építőpáholy szerkesztési anyakulcsát követték. Ržiha szerint a strasbourgi páholy anyakulcsa a négyzet (quadratura), a kölni páholyé a háromszög (triangulá-
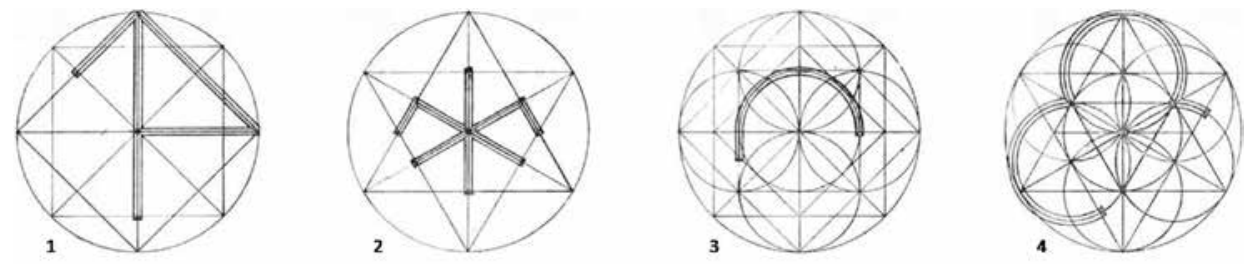

2. ábra. Kőfaragójelek a négy fö szerkesztési kulcs szerint: 1. Strasbourg, 2. Köln, 3. Bécs, 4. BernPrága (forrás: Frőde 1900. 424)

\footnotetext{
${ }^{7}$ Henszlmann 1880. 9. Mindazonáltal Henszlmann elmélete pozitív visszhangra talált, amikor 1852-ben Londonban elöször mutatta be eredményeit (Zádor 1966. 218-227, függelék), később pedig 1860-ban Párizsban publikálta az ókorra vonatkozó elméletet. Henszlmann 1860. Viollet le Duc - habár nem minden részletében tartotta elfogadhatónak - szintén üdvözölte a mü megjelenését. Forster Irattár K133; Max Hasak: Die romanische und die gotische Baukunst. Stuttgart 1902. 211 alapján.

${ }^{8}$ Forster Irattár K133.

${ }^{9}$ Henszlmann a középkori tervezést nem a számsorozat, hanem annak szerkesztett változata, a köbháromszög-ábra alkalmazásával képzelte el. Henszlmann 1864. 46.

${ }^{10}$ Myskovszky 1878. 108-111, utóirat.

${ }^{11}$ Myskovszky 1878. 107. Az aranymetszésnek a gótikában általános érvényü használatát a bártfai szentségház részletes vizsgálatán és a sedleci monstrancia említésén kívül más példákkal nem támasztotta alá.
} 
ció), a bécsié négykaréjos (Vierpas), Berné pedig háromkaréjos (Dreipas) volt ${ }^{12}$ (2. ábra). Frőde helyreállítási munkája során gyüjtötte össze a felvidéki kőfaragójeleket, amelyekben a páholyok anyakulcsait kereste, hogy ez alapján mühelykapcsolatokat állapítson meg. ${ }^{13} \mathrm{~A}$ Ržiha által meghatározott négy fö kulcs mellé egy ötödiket is bevezetett, amely a háromszög és a négyzet keverékéböl állt, ezzel azonban nem oldotta fel Ržiha elméletének ellentmondásait, az ugyanis legtöbbször összeegyeztethetetlen a morfológiai és történeti megalapozottságú műhelykapcsolatokkal, a kőfaragójelek területi eloszlása pedig nem követi meggyőzően a négy anyakulcsnak megfelelő csoportosítást. ${ }^{14}$

Möller István (1860-1934) ugyan nem publikálta a témában elért eredményeit, de a BME Építészettörténeti és Mủemléki Tanszék Rajztárában és a Forster Gyula Nemzeti Örökségvédelmi és Vagyongazdálkodási Központ Kézirattárában őrzött hagyatéka alapján méltán sorolhatjuk a téma jelentős kutatói közé. Kéziratos visszaemlékezései alapján már 1888-tól érdeklődhetett a téma iránt, amikor a Múemlékek Országos Bizottságánál Henszlmann mellett dolgozva megismerhette annak elméletét, és felismerte hibáit. Ez is inspirálhatta, hogy a geometriai szempontú elemzés műemlék-helyreállító munkáinak fontos kérdésévé vált. ${ }^{15}$ A BME Építészettörténeti és Mủemléki Tanszék Rajztárában nagy mennyiségü sablon és szerkesztési kísérlet található a gyulafehérvári székesegyház ${ }^{16}$ és a kolozsvári ferences templom profiljairól. ${ }^{17}$ Miután a világháború kitörésével legfontosabb müemléki helyreállításai félbeszakadtak, és ezeket a trianoni békeszerződés után elcsatolt területeken - így Gyulafehérváron és Kolozsváron - később nem folytathatta, érdeklődése mindinkább az összegyüjtött adatok elemzése felé fordulhatott. 1928 körül állíthatta össze azt a kéziratot, melyre a középkori mesterek által alkalmazott arányrendszerekről és szerkesztésekről alkotott elméletének összegzéseként tekinthetünk. ${ }^{18} \mathrm{Az}$ emlékek vizsgálatában alaposság és körültekintés, a hipotézisek felállításában óvatosság jellemezte: a profilokról minden esetben sablonmintát, lenyomatot vett, majd a profilok metszetén szerkesztési módszerekkel (háromszöges és négyszöges hálókkal, érintökörös szerkesztésekkel, körzős átforgatásokkal stb.) kísérletezett, míg többszöri próbálkozás után megelégedett a hipotézissel (3. ábra). A szerkesztésekhez bizonyítottan felhasználta Matthes Roriczer késő gótikus mintakönyveit,${ }^{19}$ de ezenkívül más

\footnotetext{
${ }^{12}$ Franz Ržiha: Studien über Steinmetzzeichen. Bécs 1883. Frőde szerint a háromkaréjos kulccsal szerkeszthető kőfaragójelek a prágai páholyhoz is nagy számban köthetők. Frőde 1900. 422.

${ }^{13}$ Frőde 1900.

${ }^{14}$ Bővebben Csemegi 1936. 17.

${ }^{15}$ Kérdéses, hogy Möller az eredeti középkori szerkesztési módszereket kutatta, vagy csupán egzakt, követhető szerkesztési útmutatót kívánt-e a helyreállítási munkákat kivitelező kőfaragók rendelkezésére bocsátani. A lehetőségek közül az előbbi valószínű, mivel a BME Építészettörténeti és Műemléki Tanszék Rajztárának (a továbbiakban BME Éptört Rajztár) rajzain (sablonok, profilszerkesztések) az 1916-os dátum szerepel, amikor mind a kolozsvári, mind pedig a gyulafehérvári munkálatok a végükhöz közeledtek.

${ }^{16}$ BME Éptört Rajztár 102621-102803.

${ }^{17}$ BME Éptört Rajztár 102439-102543.

${ }^{18}$ Forster Irattár K133.

${ }^{19}$ BME Éptört Rajztár 102478; 102482.
} 

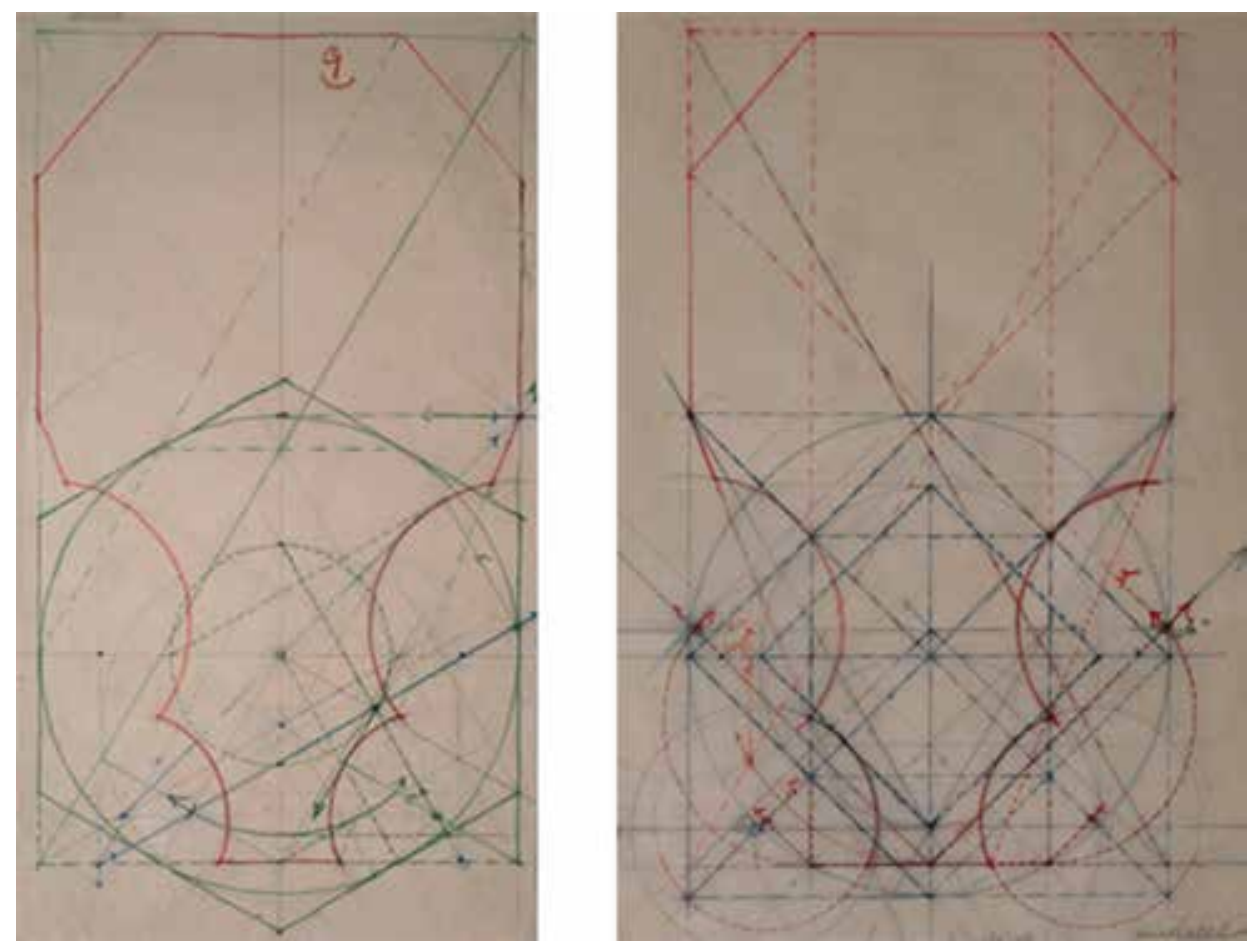

3. ábra. Möller István profilszerkesztései, 1916 (Kolozsvár, ferences templom) (forrás: BME Éptört Rajztár 102506, 102508)

egykorú forrásokat is tanulmányozott, például a milánói dóm építészeti vitájának évkönyvét, továbbá jegyzeteiben a 19. századi szerzőket és eredményeiket is áttekintette. ${ }^{20}$ Sajnálatos, hogy Möller István gondolatai nem kerültek a köztudatba, hiszen mérnöki szemlélettel elsőként ismerte fel a geometria tervezéstechnikai értékét. A szerkesztések hátterében szerkezeti és esztétikai megfontolásokat feltételezett, és felismerte, hogy ezek helytől, időtől, mestertől, iskolázottságtól függően változtak. ${ }^{21}$

Jeles müvészettörténészünk, Gerevich Tibor (1882-1954) a 20. század elején egyik korai tanulmányában foglalkozott a középkori építészet geometriai kérdéseivel, amelyben Möllerhez hasonlóan bírálta a henszlmanni elmélet tévedéseit. ${ }^{22}$ Gerevich új - mütörténeti - szempontként az építészet iparszervezetével hozta öszszefüggésbe a középkori szerkesztőmódszereket. Összefoglalta a témában addig elért eredményeket, és első ízben rendszerezte Európa középkori építészetét a geometriai sajátosságok alapján. Elmélete szerint a német gótikát - amelyre az építőpáholyok voltak jellemzőek - az arányszámok halmozása és a geometria túlzottan

\footnotetext{
${ }^{20}$ Forster Irattár K133/2.

${ }^{21}$ Forster Irattár K133/2.

${ }^{22}$ Gerevich 1910.
} 
bonyolult alkalmazása határozta meg. Ezzel szemben a francia, itáliai és magyar építészetben - amelyekre a céhrendszer volt jellemző - az arányokat és szerkesztéseket mértékkel használták, ami változatosabb formákat eredményezett. ${ }^{23}$ Habár eredményei vitathatóak, Gerevich az építész szakma középkori szervezetének elemzésével új irányt nyitott a magyar kutatástörténetben, amely később többeket ösztönzött arra, hogy komplex módon vizsgálják a témát.

Horváth Henrik (1888-1941) müvészettörténész Gerevichhez hasonlóan több szempontból közelítette meg a szerkesztésmódok kutatását. Ahogy Frőde Vilmos, úgy ő is elsősorban a kőfaragójelekkel foglalkozott Buda középkori építészetének tanulmányozása során, eredményei azonban nem csak e téren értékesek. Ismertette a páholyok müködését, a trianguláció magyarországi példáit, a kőfaragójeleknek pedig - a ržihai elmélet bemutatása mellett - történeti és szimbolikus jelentőségét is kiemelte. ${ }^{24}$ Horváth munkája leginkább azért jelentett elörelépést, mert Möllerhez hasonlóan felismerte a geometriai formák építészeti tervezésben játszott szerepét. A 19. századi kutatók legfőbb tévedésének azt tartotta, hogy helytelenül saját koruk matematikai és geometriai ismereteit használták ahelyett, hogy a középkori ember fejével gondolkoztak volna. ${ }^{25} \mathrm{~A}$ mütörténészi szemléletnek megfelelően kutatásait elméleti úton, középkori esztétikai művek és más egykorú források - tervek, mühelyrajzok, a milánói dóm vitájának jegyzőkönyve, Villard de Honnecourt vázlatkönyve stb. elemzésével is megalapozta. Horváth a szerkesztési módszerekben a középkor szellemiségét vélte felfedezni: a szabályok nem akadályozták a középkori mestereket mủvészi szabadságuk és kreatív alkotóképességük kibontakoztatásában, hanem megfelelő keretet és eszközöket biztosítottak hozzá. ${ }^{26}$

Csemegi József (1909-1963) a 20. század derekán jelentős munkásságával tudatosította a magyar kutatókban és mủemlékekkel foglalkozó szakemberekben a középkori szerkesztések ismeretének fontosságát. Möller tanítványaként gondolkodásmódjában, munkamódszerének szisztematikusságában és pontosságra való törekvésében találhatjuk meg a mestere által elkezdett, de be nem fejezett munka folytatását. Komplex látásmóddal, minden addiginál több szempontból - így az iparszervezet, a társadalmi folyamatok összefüggésében és az egykorú források tükrében - vizsgálta a témát. Mérnök-építészi szemlélettel tudatosan elemezte a szerkesztési módszereket, mint a tervezés eszközeit, és ezek ismeretét fel is használta helyreállítási, épületkutatási munkái során. ${ }^{27} \mathrm{~A}$ fennmaradt csekély mennyiségü forrás (tervrajz, mintakönyv, vázlatkönyv, vers stb.) ismertetése mellett elsőként publikált kutatástörténeti áttekintést a 19. századi szerzőktől kezdődően, továbbá példákkal illusztrálva ismertette a tervezéstechnikai módszerek alakulásának középkori történetét. ${ }^{28}$ Munkássága nem érintette az egyetemes vagy a magyar középkori épületállomány

\footnotetext{
${ }^{23}$ Gerevich 1910. 59-60, 72-73.

${ }^{24}$ Horváth 1935.

${ }^{25}$ Horváth 1935. 69.

${ }^{26}$ Horváth 1935. 25.

${ }^{27}$ Csemegi 1935, 1941.

${ }^{28}$ Csemegi 1936, 1953.
} 
egészét, a részterületek elemzését azonban olyan körültekintéssel végezte, hogy eredményei a szakirodalom kiemelkedően fontos állomásának tekinthetők. A szerkesztési módszerek és a geometria elemzésével meghatározta a késő gótikus szentélykörüljárós csarnoktemplomok fejlödéstörténetét, melyben Hans Stethaimer

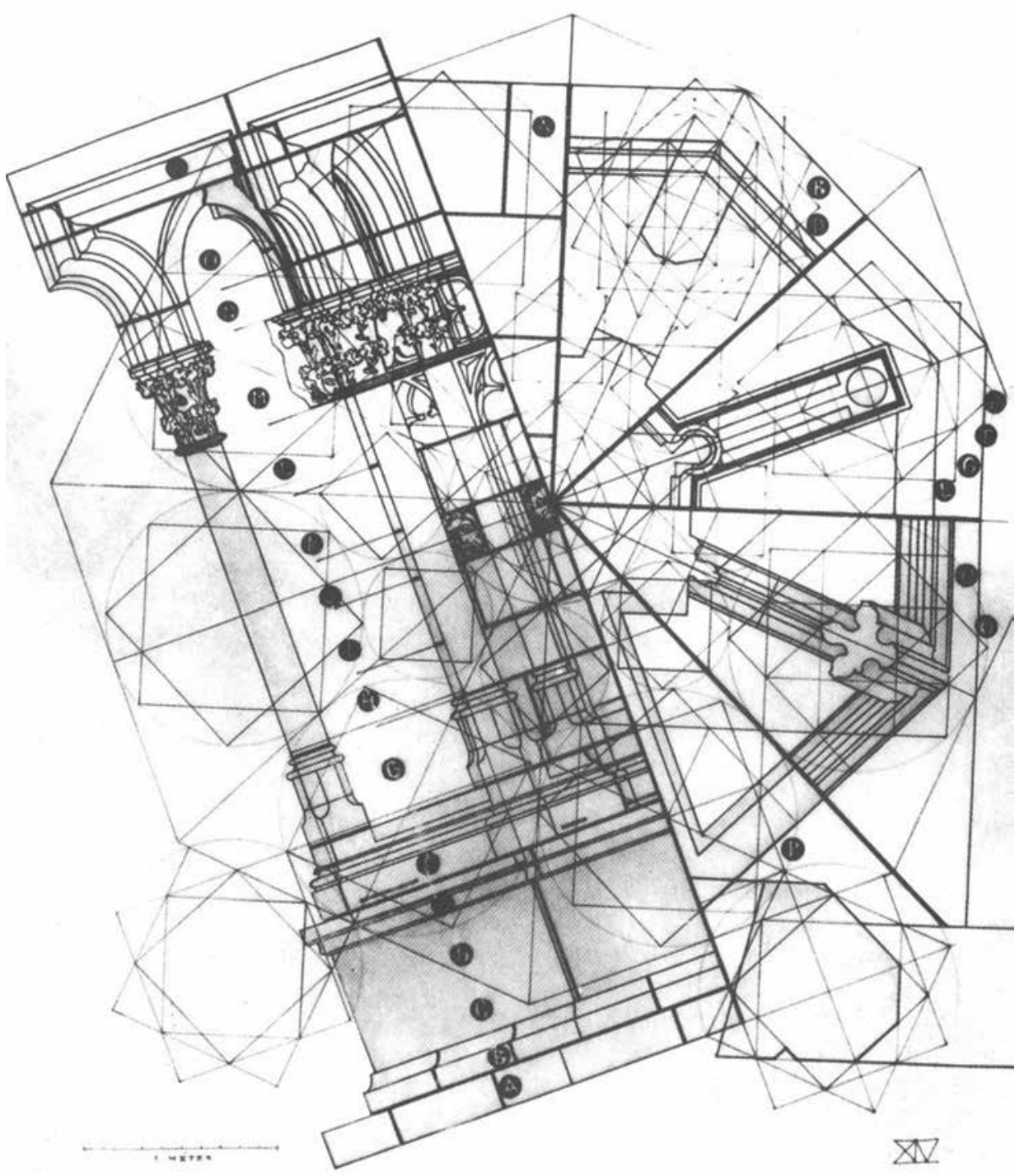

4. ábra. Szakál Ernő terve a visegrádi Anjou-kori kútház rekonstrukciójára, 1964 (forrás: Szakál 2007. 118) 
építészi egyéniségének megnyilvánulását is kiemelte. ${ }^{29}$ Hasonlóan átfogó tanulmányban foglalkozott Közép-Európa román kori centrális templomaival is, amelyben a geometriai formák szimbolikus jelentésére hívta fel a figyelmet. ${ }^{30}$

Várnai Dezsö (1910-1975) az esztergomi királyi palota kutatása kapcsán az épületek és a kőfaragójelek geometriai sajátosságait vizsgálta. Munkássága inkább a geometriai alapokon álló mühelykapcsolat-rendszer felállításának kísérlete miatt tanulságos. A ržihai mesterjegy-elméletből kiindulva - de azt sajátosan kezelve - mintegy 178 összegyüjtött kőfaragójel alapján állapította meg az építkezések periódushatárait. ${ }^{31}$ A megszokott trianguláción és quadraturán alapuló föpáholycsoportok helyett Várnai leginkább háromszöges (ill. hatszög, hatágú csillag) és ötszöges (ill. ötágú csillag) hálókat vélt felfedezni a kőfaragójelek és az épületek geometriájában. Az ötszög feltételezésével egy, a szakirodalomban és a középkori gyakorlatban is igen ritkán előforduló síkidom használatának vizsgálatát nyitotta meg a kutatás történetében. Várnai szerkesztéseinek helyessége - precizitásuk ellenére vagy éppen túlzott precizitásuk miatt - első látásra is megkérdőjelezhető. A kőfaragójelek formáját igen bonyolult eljárásokkal igyekezett igazolni, nem véve tudomást arról, hogy maguknak a jeleknek a faragását a mesterek aligha végezték hasonló alapossággal. A láthatóan szabálytalan jelek gyakran egyáltalán nem is illeszkednek a rájuk feszített hálókra. ${ }^{32}$ Várnai Dezső áldozatos munkája leginkább arra mutat rá, hogy a kőfaragójelek geometriai szerkesztettségét nem érdemes túlértékelni, és ezek téves eredményekre vezethetnek a páholy- és mesterkapcsolatok megállapításakor.

Szakál Ernő (1913-2002) kőszobrász-restaurátorként rekonstrukciós munkái (visegrádi Anjou-kori kútház, Mátyás oroszlános kútja, siklósi vár zárterkélye stb.) (3) $^{33}$ során fedezte fel a szerkesztések és geometria elengedhetetlen fontosságát és szépségét a középkori művészetben (4. ábra). Alkotó mesteremberként talán ő állt legközelebb a középkori kőfaragók gondolkodásmódjának megértéséhez, hiszen munkájában a tervezés (szerkesztés) és a kivitelezés elválaszthatatlanul összefonódott, ahogyan a középkorban is. Egykorú források - a Sankt Gallen-i kolostorterv, a Cesare Cesariano által közölt milánói dómalaprajz - ismeretével megcáfolta a kőfaragójel-elméletben gyökerező elterjedt nézetet, hogy a geometriai alapidom (trianguláció vagy quadratura) kizárólagosan egy-egy páholyra utal. Szerinte a középkori mesterek a különböző szerkesztésmódokat egyaránt használták az építészeti feladatnak megfelelően. ${ }^{34}$ Szakál meglátásai nem a tervezéstechnika kronológiájában vagy konkrét épületcsoportok elemzésében, hanem az általános, de alapvető és elengedhetetlenül fontos jellemzők összefoglalásában hoztak értékes újdonságokat: a szerkesztőmódszereket - legyenek egyszerüek vagy bonyolultak - nem kötelező érvényü szabályokként kell értelmeznünk, hanem eszközökként, amelyek korántsem gátol-

\footnotetext{
${ }^{29}$ Csemegi 1937.

${ }^{30}$ Csemegi 1960.

${ }^{31}$ Várnai 1974.

${ }^{32}$ Várnai 1974. 88-96.

${ }^{33}$ Helyreállítási munkáinak jegyzékét lásd Szakál 2007. 130.

${ }^{34}$ Szakál 1978. 98.
} 


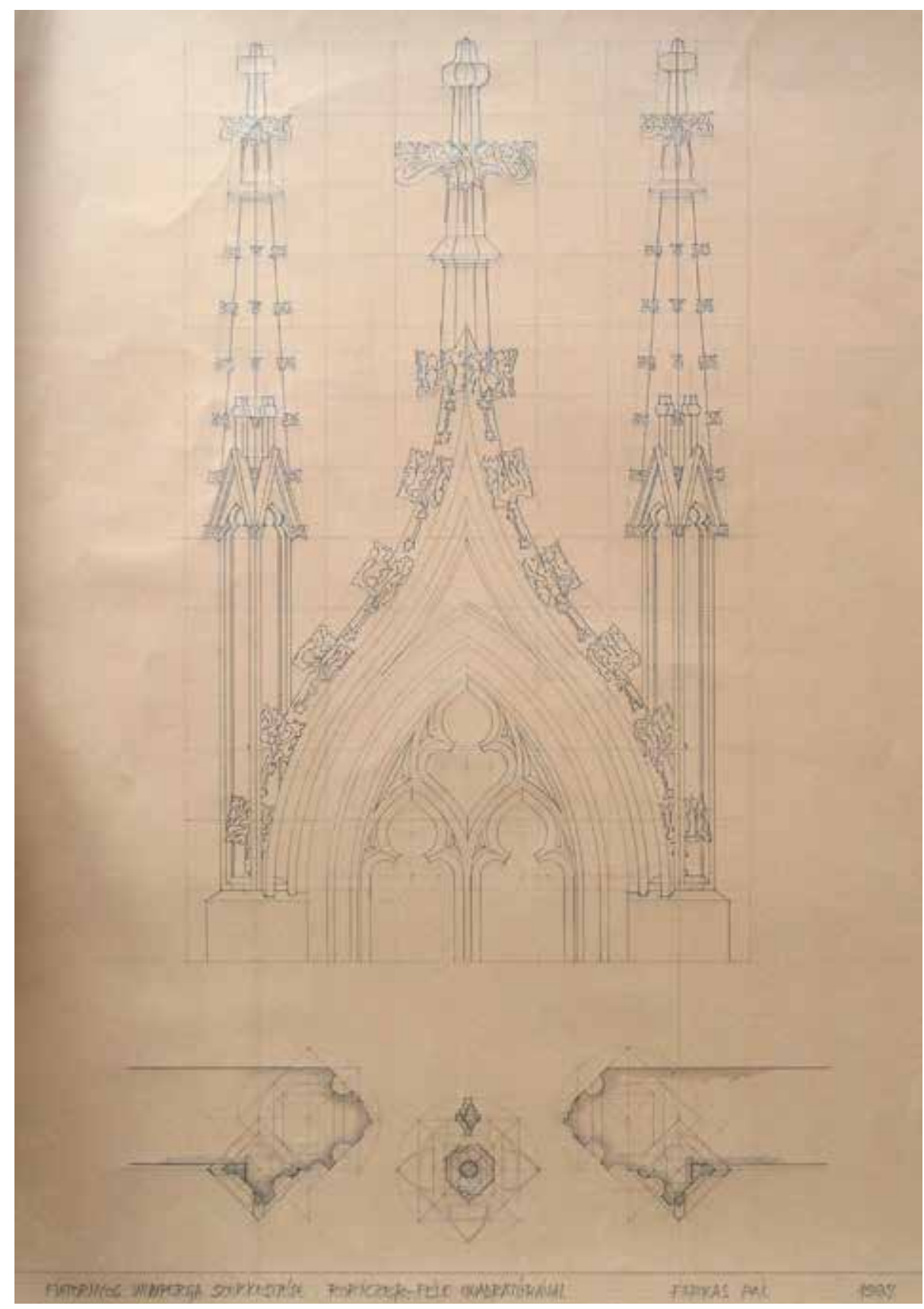

5. ábra. Wimpergaszerkesztés Roriczer mühelykönyve szerint, szakmérnöki rajzfeladat, 1987 (forrás: BME Éptört Rajztár 100022) 
ják, hanem inkább szabadjára engedik a müvészi alkotás folyamatát. Szakál munkássága tehát azért fontos a kutatástörténetben, mert az addig képviselt mủvészetelméleti és mérnök-építészi szemléletet a kőszobrász-mester sajátos gondolkodásával egészítette ki. ${ }^{35}$

Sódor Alajos (1920-2008) kutatásaira - Csemegihez hasonlóan - igényesség, körültekintés és komplex látásmód volt jellemző. Meghatározta az építési folyamatot előkészítő módszerek teljes középkorra vonatkozó történetét, a legfontosabb egykorú forrásmunkák - Villard de Honnecourt, Matthes Roriczer, Hans Schmuttermayer - elemzésével pedig hiánypótló munkát végzett el.$^{36}$ Kandidátusi értekezésében elméleti úton, az építészeti forrásmunkák mellett a középkori esztétika és filozófia szempontjából is értelmezte a témát. ${ }^{37}$ A középkort három fö szakaszra osztotta, amelyekhez példaértékủ müveket határozott meg: az antiktól kezdve a romanika végéig Cluny III templomát; az érett gótikában Villard de Honnecourt vázlatkönyvét; a késő gótikában pedig, amikor a reneszánsz hajnalán a páholyszervezetek felbomlása az ott felhalmozott tudás elveszésével fenyegetett, a német mintakönyveket. ${ }^{38}$ A középkori szerzők mellett nagy jelentőséget tulajdonított Vitruviusnak és az antik hagyományok továbbélésének a középkori tervező tevékenységben. Sódor kutatási eredményei mellett igen jelentős, hogy a BME Építészettörténeti és Elméleti Intézet Mủemlékvédelmi Szakmérnöki Képzésének keretei között a középkori tervezési módszerek ismertetését az oktatásba illesztette ${ }^{39}$ (5. ábra). Ezzel a szakma szélesebb körében tudatosulhatott, hogy a helyreállítási tevékenység és az épületkutatás elengedhetetlen részterületéről van szó.

Czagány István (1926-1988) Sódor tanítványaként (6. ábra) a középkori szerkesztéseket - tervezési módszerként értelmezve - a budavári emlékanyag csoportosítására, periodizálására használta. Először a budavári ülőfülkék alaktani tipológiáját egészítette ki geometriai megfigyelésekkel, ${ }^{40}$ utóbb pedig az egész középkori Budavár anyagát vizsgálta. ${ }^{41}$ Hangsúlyozta, hogy a szerkesztések elemzése, rekonstruálása fontos munkamódszere kell, hogy legyen az épületek kutatásának és a helyreállítások előkészítésének. Felismerte, hogy a téma tudományággá nőtte ki magát, és szorgalmazta a mintegy 120 éves kutatás módszertani történetének megírását. Habár célkitüzései helyesek voltak, eredményei csak részben tekinthetők elfogadhatónak. Czagány elsődleges forrása a budai emlékanyagról saját felmérése volt (alaprajzok, épületrészek, profilrajzok), amelynek elsősorban morfológiai elemzését végezte el, ettől azonban szerkesztéstechnikai tipológiájának felállításakor érezhetően nem tudta függetleníteni magát. Eredményei leginkább azért kérdőjelezhetők meg,

\footnotetext{
${ }^{35}$ Szakál 2007; Császár 2001.

${ }^{36}$ Sódor 1978b, 1981, 1982.

${ }^{37}$ Sódor 1974.

${ }^{38}$ Sódor 1978a.

${ }^{39}$ A BME Építészettörténeti és Műemléki Tanszékének Müemlékvédelmi Szakmérnöki Képzésén jelenleg is tananyag.

${ }^{40}$ Czagány 1978.

${ }^{41}$ Czagány 1985.
} 


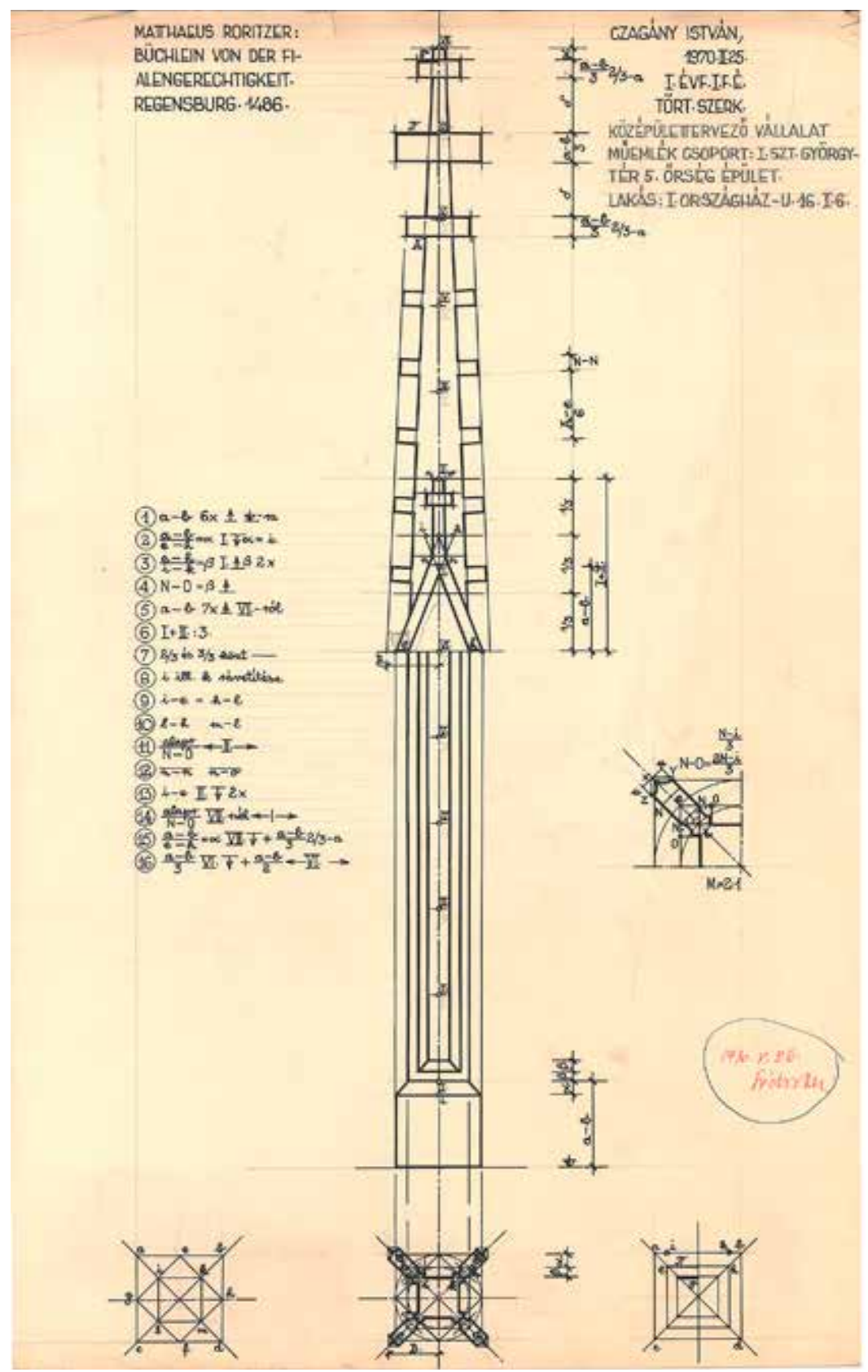

6. ábra. Fiatorony-szerkesztés Roriczer műhelykönyve szerint, Czagány István szakmérnöki rajzfeladata, 1970 (forrás: BME Éptört Rajztár 103265) 
mert szerkesztési hipotézisei láthatóan nem egy-egy rajz előállításának kizárólagos lehetőségét adják meg, mégis messzemenő mühelykapcsolati következtetéseket vont le belölük. ${ }^{42}$ Ennek ellenére a szerkesztési módszerek időbeli változásáról alkotott nézetei - minél bonyolultabb a szerkesztés, annál később készült, illetve a 30-45$60^{\circ}$-os szerkesztővonalak időbeli sorrendje - figyelemre méltók és megfontolásra érdemesek.

Sedlmayr János (1932-2004) műemlékfelújító munkái során minden bizonnyal gyakran szembesült a középkori szerkesztések, tervezési módszerek problémájával. Szakirodalmi munkásságában ennek nyomát leginkább a soproni Szent Mihálytemplom két mérmúves ablaka kapcsán láthatjuk..$^{43}$ Ismertette a mérmüves ablakokon gyakran alkalmazott érintőkörös szerkesztések jellegzetességeit és az ötszög szerkesztésének Hans Hammer által javasolt módját. Sedlmayr tanulmánya fontos része a kutatástörténetnek, későbbi munkássága azonban a mérmüvek tipológiáját és kronológiáját inkább alaktani szempontból tartalmazta.

Sztanekné Apai Gabriella, Sódor Alajos szakmérnök-tanítványa doktori disszertációjában Magyarország késő gótikus kápolnáinak történeti vizsgálatán kívül a geometriai szerkesztéseket is elemezte. Apai kérdésfelvetése indokolt: az emlékeken Lorenz Lachernél és más középkori forrásokban lévő szentély- és profilszerkesztési szabályok középkori használatát próbálta bebizonyítani. Sajnálatos módon a vizsgált emlékek mintavétele megkérdőjelezi az eredmények általános érvényüségét, amit maga a szerző is elismert. ${ }^{44}$ Apai disszertációja leginkább azért jelentős, mert összefoglalta egy konkrét középkori tervezési problémakörrel, a szentélyszerkesztéssel kapcsolatos egykorú feljegyzéseket. ${ }^{45}$ Ezeknek a módszereknek a pontos alkalmazását nem tudta a vizsgált emlékanyagban teljes körüen kimutatni, a quadratura használatát azonban minden alaprajz és profil esetében következetesen bizonyította. Eredményei Szakál Ernő azon meglátásait támasztják alá, hogy a középkori szerkesztések nem szabályok, hanem lehetőségek, eszközök voltak, amelyek minden építőmesternek rendelkezésére álltak.

Guzsik Tamás (1947-2002) életmüvének fontos részét képezte a középkori örmény szakrális építészet kutatása, amely során a szerkesztések elemzésével is foglalkozott. ${ }^{46}$ Zvartnoc és Ani templomainak alaprajzi szerkesztését (7. ábra) egészen a

\footnotetext{
${ }^{42}$ Pedig Czagány éppen azt emelte ki Steindl Imre és Schulek Frigyes megfigyelései közül, hogy Henszlmann-nal ellentétben felismerték, hogy a középkori részletek többféle módon kiszerkeszthetők, és egyegy épületen belül több séma is jelen van. Czagány 1985. 399.

${ }^{43}$ Sedlmayr 1992.

${ }^{44}$ Apai 1980. Függelék 6. A geometriai vizsgálatokat az OMF Tervtárában fellelhető anyagon végezte el, amelyet csak esetenként tudott saját felmérésekkel kiegészíteni.

${ }^{45}$ Forrásai: Roriczer és Schmuttermayer (quadratura), Lorenz Lacher 1516-os „Unterweisungen”-je (12 szabály szentélyszerkesztésre), az ún. Bécsi mintakönyv (késő gótikus boltozatok rajzai), a des Chores Mass címü kézirat a 17. század közepéről (gótikus szentélyalaprajz-szerkesztés). Apai 1980. Függelék 1-2. A szentélyszerkesztési szabályok kigyüjtéséhez érdekes adalékul szolgálhatnak Villard de Honnecourt vázlatkönyvének szentélyrajzai is, bizonyítékául annak, hogy a kérdés a 13. században a komplikáltabb építészeti feladatok közé tartozott.

${ }^{46}$ Guzsik 1990.
} 


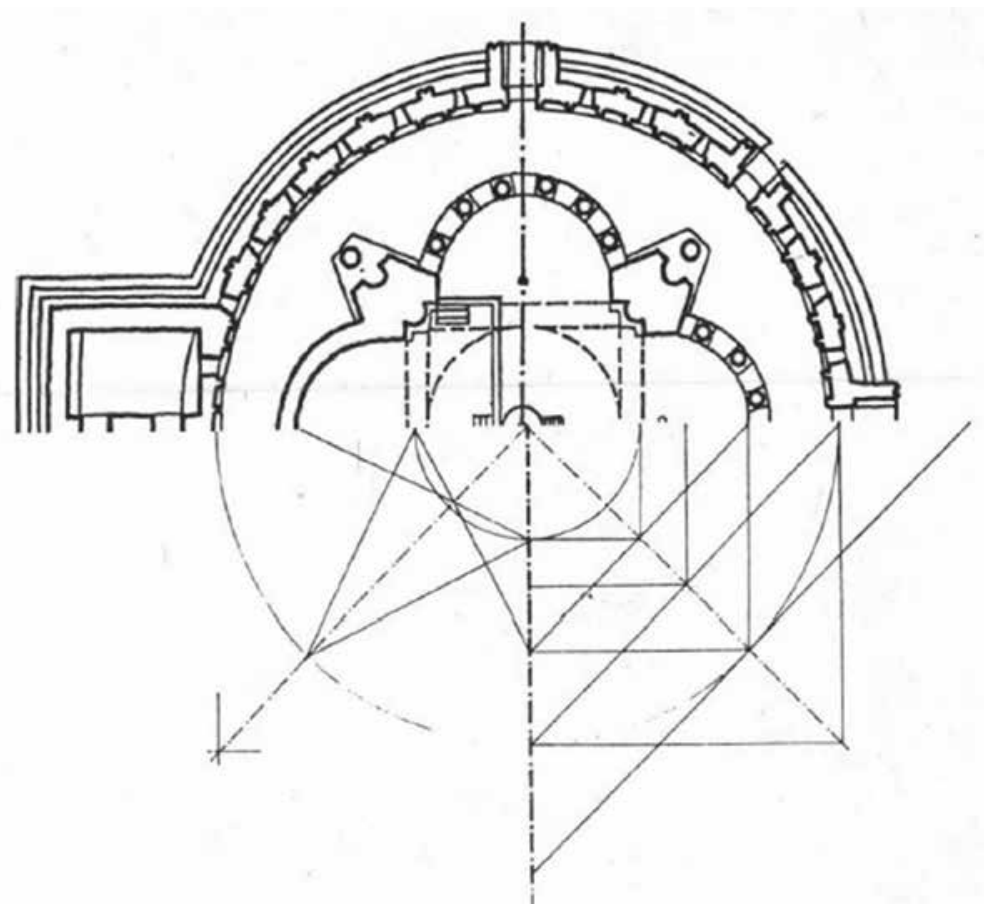

7. ábra. A zvartnoci templom alaprajza és szerkesztőhálója (forrás: Guzsik 1990. 149)

jeruzsálemi Szent Sír Rotundáig vezette vissza a geometria szimbolikus tartalmának azonossága alapján. Ezzel a geometriai alapidomok fontos, de ritkán említett értelmezését fejtette ki, amivel előtte csak Csemegi József foglalkozott. ${ }^{47}$ Guzsik munkája arra is rámutat, hogy a quadratikus és trianguláris rendszerek már a gótikánál jóval korábbi építészetben is fontos szerepet játszottak, kevésbé szerkezeti, mint inkább szimbolikus megfontolásból. Szakított tehát azzal a korábbi nézettel, mely szerint a geometrikus szerkesztőhálók elsősorban a gótika szerkezeti újításaival összefüggésben kerültek előtérbe, míg azt megelőzően egyszerủ arányszámok, esetleg a négyzet sorolása volt a jellemző tervezési módszer.

Hoppe László az 1990-es években kezdte a középkori tervezéselmélet és méretmeghatározás kérdéseinek kutatását részben saját helyreállítási munkái alapján (Csaroda, Vámosatya), részben pedig középkori források (Hans Hammer stb.) elemzésével. Az eddigiekhez képest új szempontokat vizsgált, ilyen a középkorban ritkán alkalmazott ötszög szerkesztési módszereinek összegyüjtése ${ }^{48}$ és a mértékegy-

\footnotetext{
${ }^{47}$ A szabályos sokszögek és más geometrikus idomok allegorikus értelmezésével szemben a számok szimbolikus jelentéseiröl több kutató is írt (Gerevich Tibor, Sódor Alajos, Guzsik Tamás).

${ }^{48}$ Hoppe 1995.
} 
ség-használat. ${ }^{49} \mathrm{Az}$ utóbbi kérdés azért jelent újdonságot a kutatástörténetben, mert a fennmaradt csekély számú tervrajz kótázatlan volta arra enged következtetni, hogy a tervezési fázisban nem a konkrét méretek, hanem a különböző arányosságok játszottak fontos szerepet. Elemezte továbbá a 19. században született elméleteket, melyeknek két fö hibáját ismerte fel: önkényesen megalkotott rendszereket erőltettek rá a müemlékekre, illetve minden épület arányaiban harmóniát feltételeztek, amelynek jelenléte azonban Hoppe szerint a funkció függvénye. ${ }^{50}$

Szekér György Sódor Alajos tanítványaként és a Mủemléki Szakmérnöki Képzésben utódjaként oktatja a középkori szerkesztések tervezéstechnikai jelentőségét. Kutatómunkáit (pécsi székesegyház, pécsi domonkos templom, a diósgyőri vár fülkeboltozata, füzéri várkápolna) az egykorú források, mintakönyvek, szabálykönyvek ismeretével végzi. ${ }^{51}$ Epületrekonstrukciós helyreállítási tevékenysége során készség szinten használja a középkori tervezéstechnikai ismereteit, ekképpen munkássága a Szakál Ernő által megkezdett úton halad. ${ }^{52}$

A magyarországi kutatástörténeti összefoglalóból látható, hogy az eddigi tanulmányok leginkább a müemlékvédelmi helyreállításokhoz vagy az épületek igényes történeti kutatásához kapcsolódtak. Mint ahogyan a műemléki vizsgálatok terén egyre nélkülözhetetlenebbé válik a számítógépes adatfeldolgozás és modellezés, úgy a középkori szerkesztőmódszerek tekintetében is kézenfekvőnek látszik a számítógépes technika előnyeinek kihasználása. E téren említhetjük Strommer Lászlót, aki doktori disszertációjában történeti boltozatok CAD programokkal történő szerkesztését, elemzését dolgozta ki. ${ }^{53}$ Szőke Balázs több késő gótikus háló- és csillagboltozat számítógépes rekonstrukcióját végezte el a közelmúltban, ${ }^{54}$ amelyek kapcsán néhány szerkesztési módszert is ismertetett. ${ }^{55}$ Habár Szőke általánosságban a 15. század végi eljárásokra hivatkozott, ${ }^{56}$ mégis szemmel látható, hogy sem ő, sem Strommer nem törekedett az ismert középkori forrásokban fellehető szerkesztőmódszerek bizonyítására vagy használatára. A számítógépes technika a kutatás jövőjében leginkább a pontos $^{57}$ és nagy adatmennyiséggel dolgozó felmérésekben hasznosítható. A középkori emlékanyag fotogrammetrikus feldolgozásában látta Sztanekné Apai Gabriella ${ }^{58}$ is a vizsgálódás új alapokra helyezését.

\footnotetext{
${ }^{49}$ Hoppe 1994.

${ }^{50}$ Hoppe 1993. 355-358.

${ }^{51}$ Szekér 1992. 19.

${ }^{52}$ Szekér 2014. 31.

${ }^{53}$ Strommer 2008.

${ }^{54}$ Szőke 2009.

${ }^{55}$ Szőke 2005.

${ }^{56}$ Szőke 2009. 444.

${ }^{57} \mathrm{~A}$ felmérési pontosság a vizsgált emlékanyag függvényében fontos. Egész épületalaprajzok, metszetek esetében a hibahatár jóval nagyobb, mint a kis épületrészek, profilok vizsgálatakor, mert a kitüzésből és alakváltozásokból komoly méretkülönbségek keletkezhetnek az eredeti tervhez képest. Guzsik 1975. 92. Részletek vizsgálatakor a kis eltérések (kopás, torzulás, faragási pontatlanság) miatt fokozottan ügyelni kell a mérési pontosságra, hogy biztosabban lehessen következtetni az eredetileg tervezett mintasablon geometriájára.

${ }^{58}$ Apai 1980. Függelék 12.
} 


\section{KÖZÉPKORI TERVEZÉSI (SZERKESZTÉSI) MÓDSZEREK}

Az előző fejezetben tárgyalt kutatások során felhalmozott tudásanyag mennyisége és sokrétüsége indokolja és megkívánja az eredmények tartalmi összefoglalását és rendszerezését. A középkori épülettervezés módszereinek feltárásához nemcsak a szerkesztési eljárások, hanem minden más méretmeghatározó eljárás megismerése is hozzátartozik. A feladatot megnehezíti, hogy a középkori építőmesterek gondolkodásmódja minden bizonnyal nagyon távol állt a mai építészekétől. Fogódzót jelent azonban, hogy az épülettervezést a hordozóra (papír, pergamen, gipszpadlós9 $\mathrm{stb}$.) való elörajzoláson túl szerkezeti, esztétikai, használati és szimbolikus jelentésbeli szempontok minden korban együttesen befolyásolják. A középkori és a mai tervezés közötti talán legnagyobb különbség az, hogy míg ma az épület egyes méreteit - számos konkrét elöírást is figyelembe véve - numerikusan, egymástól gyakran függetlenül adjuk meg, addig a középkor mesterei elsősorban a méretek egymáshoz való viszonyát határozták meg. Eddigi ismereteink szerint ennek eszközei a következők voltak: az antik hagyományokon alapuló modulrendszer; egyszerü számarányok, amelyek alapjai szimbolikus jelentésű számok; ${ }^{60}$ és geometriai alapidomok, hálók szerkesztéséből adódó összefüggések. A következőkben e módszerek alkalmazását a középkori építészetben kronologikus rendszerben igyekszünk áttekinteni, elsősorban a hazai kutatások eredményeinek tükrében.

\section{ÓKERESZTÉNY KORSZAK ÉS PREROMANIKA}

Az ókori hagyomány és elmélet kétségtelenül komoly befolyással volt a korai középkor müvészetére. Möller István szerint az ókeresztény építészet még őrizte az antik formanyelvet, de az oszloprendek arányai már nem követték a vitruviusi kánont. ${ }^{61}$ Mivel azonban különböző középkori tervezési módszerek az épületrészek egymáshoz való viszonyát határozták meg, közvetve mindegyiket az antik modulrendszerre vezethetjük vissza. A Vitruvius által meghatározott modulon alapuló szigorú méretrend középkori alkalmazásáról nem tudunk, de erre emlékeztető módszerekkel még a 15. század végén is találkozunk. ${ }^{62}$ A szerkesztések ősének tekinthetjük az ókori Egyiptomból ránk maradt falképeken és a csekély számú tervrajzon látható

\footnotetext{
${ }^{59} \mathrm{E}$ ritka, 1:1 méretarányú, minden bizonnyal a kivitelezést közvetlenül előkészítő tervezési módszerre az angliai Wellsben és Yorkban maradtak fenn példák. Szakál 2007. 88-90.

${ }^{60} \mathrm{~A}$ számok mellett a betük szimbolikáját is említik (betük számokkal való azonosítása alapján), de ez a különféle ábécék használata miatt igen kérdéses. Guzsik 1990. 152-153; Ritz Sándor: A templom. Róma 1985. 51-65 alapján.

${ }^{61}$ Möller István határozottan elvetette az antik tervezéstechnika középkori folytonosságát, szerinte a romanikában és a gótikában teljesen új, a korábbiaktól független szerkesztési rendszereket és formakincset fejlesztettek ki. Forster Irattár K133/2.

${ }^{62}$ A középkorban végig jelen lévő ókori hatást a mintegy 78 Vitruvius-másolat bizonyítja. Sódor 1978 a 3.
} 
négyzethálót, ami az arányok meghatározását és a rajzolást segítette. ${ }^{63}$ Hasonló módon rajzolhatták 816 körül a Sankt Gallen-i kolostortervet, ami szintén négyzethálóra illeszkedik. ${ }^{64}$ A középkori tervezés módszereit tehát nem függetleníthetjük az ókori hagyományoktól, a keresztény szellemiség azonban már új irányba terelte az építészet fejlődését.

Általánosan elfogadott nézet, hogy a bonyolultabb geometrián alapuló szerkesztések a gótikára voltak jellemzőek, az azt megelőző korszakokban az épületeket egyszerü arányszámokkal, esetleg négyzetek sorolásával határozták meg. ${ }^{65}$ Guzsik Tamás az örmény Zvartnoc székesegyházat (643-652) és Ani Gaghik-templomát (1001-1013) elemezve hívta fel a figyelmet arra, hogy a geometriai szerkesztések már az ókeresztény kortól fontos szerepet játszottak a szakrális épületek tervezésében. ${ }^{66} \mathrm{E}$ két centrális, quadratura hálóval meghatározható templomot ugyanis a geometria szimbolikus jelentéstartalma alapján a római Santo Stefano Rotondóval (325-350) és a jeruzsálemi Szent Sír-templom Anasztázisz-terével (325-333) hozta összefüggésbe ${ }^{67} \mathrm{~A}$ rokonság alapja nem morfológiai kapcsolat, hanem a koncentrikus körökből, elforgatott, sorolt négyzetekből és az ezekre szerkesztett görögkereszt formából adódó alaprajzi kompozíció szimbolikus jelentése volt. ${ }^{68}$ Guzsik szerint tehát az idomoknak örökérvényü jelentése, kommunikatív, asszociációs tartalma volt. A templomok négyoldali térbővületeit kijelölő görögkereszt Jézust, a feltámadást és az üdvösséget jelentette. A quadratura alkalmazását magyarázhatjuk számszimbolikával (pl. négy: a világ teljessége, égtájak, evangélisták stb.; vagy nyolc: a tökéletesség, nyolc boldogság stb.) vagy Agathangelosz legendájával, mely szerint Szent Gergely a két örmény vértanú, Szent Hripszime és Szent Gajané kivégzésének helyén négy felhőoszlopon nyugvó tüzes kupolát látott, benne sugárzó kereszttel. ${ }^{69}$ A geometriai idomok ilyen mélységü többletjelentése arra mutat rá, hogy az épület a középkori emberek számára kommunikációs tartalommal bírt. A megrendelő egyházi személy az építész által üzenetet tudott közvetíteni, mert a templom a liturgikus közösség minden tagjából ugyanazokat az asszociációkat hívta elő. Az alaprajzokban megjelenő geometriai kompozíció az örmény épületplasztika apotropaikus díszítőmotívumaival (körbe, négyszögbe írt fonatos kereszt szimbólumok) is hason-

${ }^{63}$ Szakál 2007. 42-44; Sódor 1978a 5; Hoppe 1993. 363-364. Az egyiptomi arányozási és geometriai módszerekről bővebben lásd: Istvánfi Gyula: Építészeti szerkesztőmódszerek az ókori Egyiptomban. ÉpitésÉpítészettudomány 42 (2014) 3-4. 159-171.

${ }^{64}$ Szakál 1978. 97; Hoppe 1993. 370.

${ }^{65}$ Forster Irattár K133/2; Csemegi 1953. 14-15.

${ }^{66}$ Guzsik 1990.

${ }^{67}$ A jeruzsálemi Szent Sír rotundája más kutatóknál is a centrális szakrális terek közös előképeként jelenik meg. Christian Sapin például a dijoni Saint Bénigne egykori Mária-rotundáját vezeti vissza rá, tágabb értelemben pedig a Szent Sír a halotti rítus tereinek őseként is értelmezhető, pl. zarándoktemplom kriptája, nyugati szentély stb. Sapin 1996. A rotundák elemzéséről bővebben lásd: Gevers-Molnár 1972.

${ }^{68}$ A Szent Sír és a Santo Stefano Rotondo esetében Guzsik Ritz Sándor eredményeire hivatkozik, de lényegesen leegyszerüsíti Ritz szerkesztéseit. Ritz Sándor: A templom. Róma 1985.

${ }^{69}$ Guzsik 1990. 151. Nincs kizárva, hogy az örmény építészetben - vagy akár az egész középkorban - szó szerint értelmezték a legendákban szereplő látomásszerü térelemeket. 

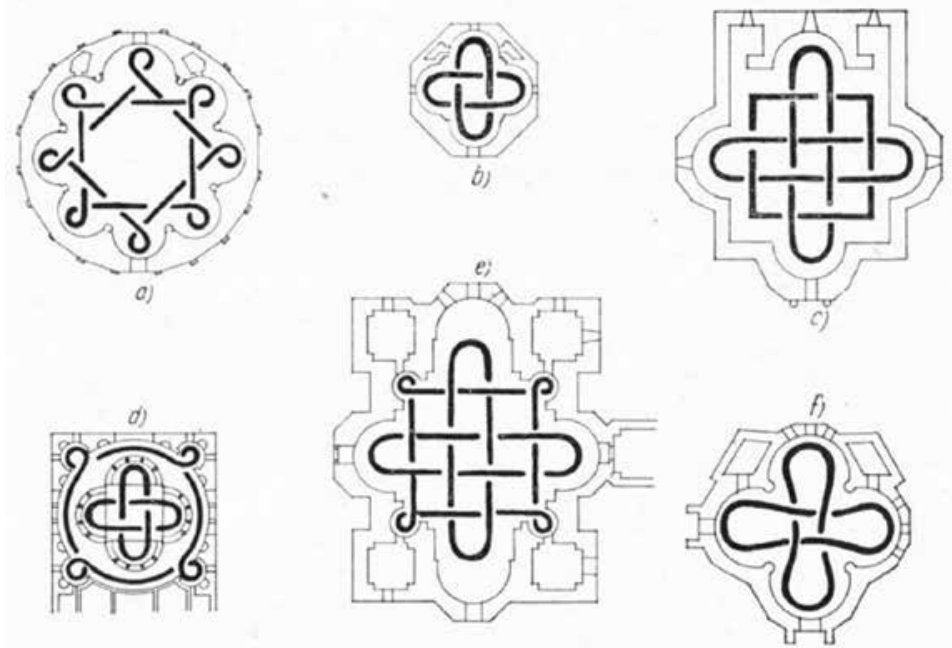

8. ábra. Apotropaikus motívumok és az örmény építészet viszonya (forrás: Csemegi 1960. 347)

lóságot mutat ${ }^{70}$ (8. ábra). A templomok alaprajzi szerkesztése és geometrikus díszítése közötti szoros kapcsolat arra enged következtetni, hogy a teljes épület és a legapróbb részletek egylényegüek, egymásból kifejezhetők. Ez nagy valószínűséggel az egész középkor építészetére jellemző lehetett. ${ }^{71}$

A szimbolika mellett természetesen a szerkezeti és kivitelezési szempontok is érvényesültek. Szintén Guzsik Tamás említi a milánói San Lorenzo-templom (350 után) bonyolult téri kompozícióját, amelynek alaprajzi kitüzését valószínüleg csak a geometriai szabályosságok segítségével tudták megvalósítani. ${ }^{72}$ A geometria kivitelezésben játszott szerepéről a kutatók egybehangzó véleménye az, hogy a terv szerint megszerkesztett alaprajzi kompozíciót 1:1-es léptékben a helyszínen újra megrajzolással tüzték ki, amihez elegendő volt egyetlen kezdőméret megadása. ${ }^{73}$ A középkori tervezés szoros kapcsolatban volt a kivitelezéssel, ezt mutatja, hogy a kitüzés és a rajzolás egyszerủ eszközei (vonalzó, körzőzsinór) lényegében megegyeztek egymással. ${ }^{74}$

A geometria korai alkalmazását tehát több okra vezethetjük vissza, de tény, hogy a helyszíni kitüzéshez legalább egy valóságos kezdőméretre szükség volt, még akkor is,

\footnotetext{
${ }^{70}$ Guzsik 1990. 153. Ilyen szimbólum található a tarnaszentmáriai Árpád-kori templom hajójának déli homlokzatán is. Csemegi 1960. 345.

${ }^{71}$ Czagány 1978. 150.

${ }^{72}$ Guzsik 1990. 140.

${ }^{73}$ Horváth 1935. 69; Sódor 1978a 10; Hoppe 1993. 366.

${ }^{74}$ Hoppe 1994. 10; Marosi 1969. 102.
} 
ha ebből akár az egész kompozíció kifejthető. ${ }^{75}$ Mivel az egykorú tervrajzokon alig láthatunk kótázást, csak következtetni tudunk a méretmeghatározó elvekre. A középkori mérési módszerek és mértékegységhasználat feltárásával Hoppe László foglalkozott, de ilyen források csak a gótika korából maradtak fenn. ${ }^{76} \mathrm{~A}$ korai időkre vonatkozóan a számok szimbolikájára hagyatkozhatunk, ahogyan azt Dhuoda grófné 843-ban fiához írt intelmei is tanúsítják. ${ }^{77}$ Gerevich Tibor szerint a leggyakoribb számok jelentése: 1 az egy Isten; 3 a Szentháromság; 4 a négy evangélista, a négy fő erény, a négy paradicsomi folyó, a négy évszak, a négy fö elem; 7 a hét fájdalmas szüz, a hét szentség az irgalmasság lelki kulcsa, a teremtés hét napja, a hét főbün, a hét szabad müvészet; 12 a tizenkét apostol, a tizenkét izraeli törzs, a tizenkét hónap, Jákob tizenkét fia. ${ }^{78}$ Guzsiknál a keresztény szimbolikában a 4 a világ teljessége, az égtájak, az evangélisták, Ezékiel látomásának „lelkes állatai”, az Apokalipszis lovasai; a 6 a Dávid-csillag; a 8 a tökéletesség stb. A nagyobb számok ezeknek az alapszámoknak a sorozatából, kombinálásából jöhettek létre, amely a jelentéstartalom halmozását, hangsúlyozását fejezte ki. ${ }^{79} \mathrm{~A}$ geometriához hasonlóan tehát a számok is asszociatív hatással voltak a hívők számára, ami rávilágít arra, hogy a középkorban a kommunikáció alapja valószínüleg sokkal inkább vizuális jellegü volt, mint manapság.

A számok jelentőségére utal az is, hogy a templomok méreteiben gyakran egyszerủ arányosságok találhatók. A geometria mellett - akár önállóan, akár vele együtt ez a módszer is a tervezés eszköztárába tartozott. Möller István és Csemegi József szerint az ókeresztény és román korra leginkább ez volt jellemzö. ${ }^{80} \mathrm{~A}$ számarányokat nem feltétlenül numerikusan adták meg, főleg a gyakran alkalmazott $1: \sqrt{2}$ és $1: \sqrt{ } 3$ aránypárok esetében, mert a középkorban valószínűleg nem ismerték a gyökvonást. ${ }^{81}$

\footnotetext{
${ }^{75} \mathrm{Az}$ alapméretböl bizonyos szabályosság szerint létrehozott többi méret rendszere az antik modulos módszerből eredeztethető.

${ }^{76}$ Hoppe 1994.

${ }^{77}$ Hoppe 1995. 139. Dhouda/Dodana grófnő 843-ban befejezett Liber manualis címü müve, amelyben Vilmos nevü fiának a számokat úgy tanította, hogy mindegyikhez a jelentéstartalmát párosította: „Az egységnél gondolj az Egy Istenre... Kettő jelenti a két testamentomot, vagy az isteni és felebaráti szeretet két parancsát. A három jelenti a tökéletest és a háromságot; aki erősen hisz benne, üdvözülni fog. A 4-es számon a négy világtájat kell érteni és a négy evangéliumot, melyeket az egész föld kerekségén hirdetnek. Az 5 jelenti az öt okos szüzet vagy a test öt érzékét. Aki ezeket tisztán és ártatlanságban őrzi, kétszeres jutalomban részesül. A 6-os számnál emlékezzél a hat vizeskorsóra és a világ hat korszakára, amelyekben jók és gonoszok vegyest voltak együtt... A 7 a lámpák és gyertyák száma, melyek az Úr házát megvilágítják; 8-nál gondolj a nyolc lélekre, akik az özönvíz alkalmával a bárkában megmenekedtek. Jelképezik azokat, akik a keresztség vizétől újjászületve méltók arra, hogy a nyolcadik üdvösséget elérjék a győzelem pálmájával. Kilencen vannak az angyalok karai, kik a megpróbáltatást szilárdul elviselték. Tíz jelenti a tizedet, melyről hisszük és valljuk, hogy az Atyák kijelentése szerint valamikor vissza fogjuk kapni (ti. a mennyekben).” Finánczy 1926. 198, 310.

${ }^{78}$ Gerevich 1910. 59, 53 szerint az építőmühelyeknek titkos nyelvük volt, amiben nagy szerepük volt a jelképeknek. A szimbolikus képi beszédet mint kommunikációs eszközt tehát készségszinten használták a középkorban.

${ }^{79}$ Guzsik 1990. 137-138.

${ }^{80}$ Forster Irattár K133/2; Csemegi 1953. 14-15.

${ }^{81}$ Hoppe 1993. 366, 368 szerint a középkori építészek és matematikusok nem ismerték az irracionális szám fogalmát.
} 
Ezeket az arányokat elsősorban geometriai módszerrel tudták előállítani, például a négyzet átlójával és különféle háromszögek alkalmazásával. ${ }^{82}$ Ilyen például a Henszlmann Imre által elönyben részesített köbháromszög (oldalainak aránya: $1: \sqrt{2}: \sqrt{ } 3$ ), amelynek középkori alkalmazását semmiképp sem szabad elvetnünk. ${ }^{83}$ Arányosító derékszögü háromszögeket és négyszögeket a rómaiak is alkalmaztak, ahogyan arra Vitruvius is utalt. A diagon 1: 2 arányú, az auron ${ }^{84}$ pedig 1:1,618, vagyis aranymetszés arányú, amelyek nemcsak antik emlékek, hanem például a római San Pietro Vecchio alaprajzában is kimutathatók. ${ }^{85}$

A számszimbolika mellett a középkori méretmeghatározásnak egy másik módja is ismeretes, ami az egész kereszténység számára kultikus jelentőséggel bíró épületek mintaadó szerepén alapszik. Salamon elpusztult Templomáról (állt i. e. 960-i. e.587) és méreteiről több írásos feljegyzés maradt fenn, ${ }^{86}$ amelyek az egész középkor folyamán mintaként szolgáltak. Ezt nem puszta másolásként kell elképzelnünk, hanem a fontos szakralitással bíró ősi épület idézeteként, amely a méretek és számok (pl. oszlopok darabszáma) által szimbolikus jelentést közvetített a közösség számára. Guzsik szerint az elökép valamilyen részletének átvétele utalás volt a középkori templom legfőbb rendeltetésére, a mennyei Jeruzsálem földi megtestesülésére. ${ }^{87}$ Ilyen mintaadó szerepe volt a jeruzsálemi Szent Sír-templomnak is, amelynek méreteit még a 12. században is átvették. ${ }^{88} \mathrm{Ez}$ arra enged következtetni, hogy az épületfelmérés gyakorlata már a korai közékorban is létezett, bár korántsem bírhatott olyan jelentőséggel, mint az antik építészetet feltámasztó reneszánsz idején. ${ }^{89}$

\footnotetext{
${ }^{82}$ A középkori gondolkodás kevésbé aritmetikai, mint inkább geometriai (vizuális) jellegét Henszlmann is felismerte. Elmélete egy bonyolult számsorozaton alapszik, aminek elemeit szerinte szerkesztéssel állították elő a középkorban. Henszlmann 1864. 46.

${ }^{83}$ Henszlmann a köbháromszögből fejlesztett sorozat alapötletét Christian Ludwig Stieglitz elméletére alapozta. Henszlmann 1864. 47. (C. L. Stieglitz: Geschichte der Baukunst der Alten. Leipzig 1792.)

${ }^{84}$ A diagon, auron és egy további arányozási mód, a hemilion a 20. században Milica Detoni és Tine Kurent által bevezetett kifejezések. Sódor 1978a 7.

${ }^{85}$ Sódor 1978 a 8.

${ }^{86}$ Bibliai leírás a mózesi Szent Sátorról, amelynek mintájára a Templom épült: Mózes II. könyve 40:1-33. Bibliai leírások a jeruzsálemi Templomról: Krónikák II. könyve 3:1-17 (építés), 4:1-22 (díszítés), 5:1-14 (felszentelés); Királyok I. könyve 6:1-38 (építés), 7:13-51 (oszlopok és díszítőmunkák), 8:1-66 (felszentelés); Királyok II. könyve 12:4-16 (felújítás); Jeremiás 52:21-23.

${ }^{87}$ Guzsik 1990. 132-135.

${ }^{88}$ Marosi 1969. 66.

${ }^{89}$ Hoppe László azzal magyarázta a középkori tervek kótázatlanságát, hogy a méretek és mértékegységek konkrét meghatározását a reneszánszban kezdődő épületfelmérő tevékenység hívta életre. (Hoppe 1993. 379.) A felmérési gyakorlat valóban ekkor válhatott olyan mértéküvé, hogy a müszaki rajzolást megteremtse. (Bővebben Hajnóczi 1956. 5-6.) Források igazolják (Marosi 1969), hogy a középkorban az egyházi méltóságok az építéssel megbízott mestert a Szent Földre küldték, hogy „elhozza” a Szent Sír rotunda méreteit az újonnan épülő templom számára. Ez azonban valószínűleg ritkán fordult elő, a méretek mennyisége pedig nem indokolta a maihoz hasonló részletezettségü felmérési rajzok készítését. Inkább elképzelhetö, hogy a méreteket szövegesen rögzítették, ahogyan a salamoni Templomról is bibliai részletek tudósítottak.
} 


\section{ROMANIKA}

A világvégevárás hangulatából felocsúdó ezderforduló utáni művészet és építészet hatalmas lendülettel fejlődött tovább. ${ }^{90} \mathrm{~A}$ tervezési és szerkesztési módszerek tekintetében a román korból is igen csekély számú forrás áll rendelkezésre, ezért továbbra is az épületekre és a segédtudományokra kell hagyatkoznunk. Az építőtevékenység már a középkor kezdetétől az egyház kezében volt, a kolostorok lettek a szakmai tudás és a mủveltség központjai. A romanika korában ugrásszerüen megnövekedő építési igény hatására létrejöttek a bencés, majd a ciszterci építőiskolák. ${ }^{91} \mathrm{~A}$ szaktudás ritkaságát és értékét mutatja, hogy a kolostori mühelyekböl gyakran kölcsönkérték az építés lebonyolításában jártas szerzeteseket más építkezésekre. ${ }^{92} \mathrm{~A}$ szaktudás és a formanyelv helyi jellegéhez hasonlóan feltételezhetö, hogy a kolostori iskoláknak egyedi tervezési módszerei is lehettek, a kutatók okkal feltételezik tehát, hogy a szerkesztések elemzése segíthet az épületek periodizálásában vagy mühelyazonosságok megállapításában. Ezt azonban fenntartásokkal kell kezelni, hiszen a geometriai alapidomokat (háromszög, négyszög) és az egyszerü arányszámokat valószínüleg széles körben használták, ezért kormeghatározásra csak az igazán különleges szerkesztési módszerek megtalálása alkalmas. Az egyes tervezési sémák nehezen köthetők mesterekhez vagy mühelyekhez, fontos felismerés azonban, hogy az egy épületen belüli szerkesztésbeli eltérések segíthetnek a periódushatárok elkülönítésében, mint arra Csemegi József a jáki templom esetében rámutatott. ${ }^{93}$

A kolostorok müvelt szerzetesei ismerték a matematika és az azon alapuló számmisztika tudományát, aminek fontos szerepe volt az épületek tervezésekor. ${ }^{94} \mathrm{Az}$ előző fejezetben már esett szó arról, hogy az általános felfogás szerint a romanikában leginkább a szimbolikus tartalmú számarányok határozták meg az épületeket. Csemegi József ezt az eschaui Saint Trophime-apátság (991) ${ }^{95}$ arányaival (1:1, 1:2:1,

\footnotetext{
${ }^{90}$ Raoul Glaber auxerre-i, majd dijoni, végül clunyi szerzetes 1002-1003-ban készített krónikájában írta: „Az említett ezredik éven túl (...) szerte az egész földkerekségen, föleg azonban Itáliában és Galliában, hozzákezdtek az egyházak építéséhez. (...) Ekkor tehát majdnem valamennyi püspöki székhely templomait és a különböző szentek többi monostorát, a kisebb falvak templomait a hívek jobbal cserélték fel.” Fordítás Marosi 1969. 63 .

${ }^{91}$ Ilyen bencés mühelyek: Hirsau, Szent Gallen, Corvey, Fleury, Rheims, Mainz, Köln, Strasbourg, Reichenau, Trier, Lüttich, Utrecht stb. Gerevich 1910. 44-46.

${ }^{92}$ Sódor 1978a 6. Vándorló szerzetes építők már a 8. századtól ismertek. Ilyen volt Etho apát Bajorországban vagy Cluny második apátja, I. Szent Odo (926-942), akit a római San Paolo-kolostor felújításához hívtak. Gerevich 1910. 45. Ez a gyakorlat olyan mértéket öltött a 12. századra, hogy szabályozások bevezetésére volt szükség, Angliából pedig ismeretes egy levélminta építeni tudó szerzetes kölcsönkérésére föúri építkezésekhez. Sódor 1978a 6.

${ }^{93}$ Csemegi József a jáki templomon végzett kutatásai alapján megállapította, hogy a hajót négyzetes hálóval elöször öt boltszakaszosra tervezték (az északi hosszfal így is épült), de végül háromszöges arányosítással négy boltszakaszt építettek, és az épület metszetét is az utóbbi szerkesztés határozta meg. Csemegi 1953. $17-18$.

${ }^{94}$ Sódor 1978a 4.

${ }^{95}$ Echau 8. században épült első apátságát 926-ban magyar támadás rombolta le.
} 
3:4, 3:5, 2:3 stb.) indokolta. ${ }^{96}$ Sódor Alajos szerint Cluny II (955-981) alaprajzában a hossztengellyel párhuzamos méretek közös alapja a 7 (7,14, 28, 35 stb. láb), míg a haránt irányúaké a 10, amiben az a középkori szemlélet tükrözödik, hogy a világegyetem rendjét ún. tökéletes számokkal $(1,2,3,4,7,8,10$ stb.) lehet biztosítani. Cluny apátságának harmadik temploma (1088-tól) alaprajzának méretei között található a 496, 531, 532, 100, melyek ilyen tökéletes számok összegei. ${ }^{97}$ Cluny III arányrendszerében a korábban már ismertetett auron (1: 1,618, aranymetszés) és diagon $(1: \sqrt{2})$ arányosság is megtalálható, ${ }^{98}$ melyek eredete Vitruviusra vezethető vissza. ${ }^{99}$ Möller és Csemegi szerint a számszimbolika mellett a romanika tervezési módszerei közé tartozott a négyzet sorolásából adódó háló alkalmazása is, mert a boltozási rendszer négyzetraszterbe kényszerítette az alaprajzi szerkesztést. ${ }^{100} \mathrm{Ez}$ azonban csak a kötött boltozási rendszerre vonatkozik, ahol a fö- és a mellékhajókat egyaránt keresztboltozat fedte, de még ebben az esetben sem valószínü, hogy a szerkesztési rendszert a térlefedés érdemben befolyásolta volna. A hajók szélességi mérete bármilyen más boltozati forma vagy síkmennyezet alkalmazása esetén független volt egymástól.

A kora középkorhoz hasonlóan a romanika tervezési módszerei között is megtaláljuk a geometriai szerkesztéseket. A tervezés geometriai alapidomai már a korai időkben is a szabályos háromszög és a négyzet voltak, amelyre szintén több példát említhetünk. Szakál Ernő szerint az ottmarsheimi Szent Péter és Pál-apátságot (11. század) quadraturával, míg Csemegi József szerint a bélapátfalvai ciszterci templom (1232) alaprajzát és főhomlokzatát triangulációval lehet megszerkeszteni. ${ }^{101}$ Csemegi a szabályos síkidomok fontosságát a Kárpát-medence centrális templomainak elemzésével is alátámasztotta. A centrális templomok és kápolnák leggyakoribb formája a nyolcszög (vagy annak karéjos változata) volt, de ezek helyett inkább a ritkább alakzatokkal, a páratlan oldalszámú idomokkal, illetve a három- és a hatszög alaprajzú épületekkel foglalkozott. Ezek ritkaságát térelméleti kedvezőtlenségükre vezette vissza: az ideálisnak érzékelt tér határai a középpontból elöre-hátra és jobbra-balra is azonos távolságra vannak. Hatszög alaprajzú térben ez nem lehetséges, míg a nyolcszögüben (és természetesen a körben) igen. Az ettől eltérő geometriai idomok alkalmazását tehát más tényezők indokolhatták, ez pedig az ókeresztény és preromán korszakban is fontos szerepet játszó szimbolikus tartalom.

\footnotetext{
${ }^{96}$ Csemegi 1953. 15. Pl. az eschaui bencés apátság arányai a teljesség igénye nélkül: 1:1, 1:2:1, 3:4, 3:5, 2:3. Csemegi 1953. 20-21. A kapuk méretei: 1: $\sqrt{2}, 1: \sqrt{ } 5$.

${ }^{97}$ Sódor 1978a 9-10. Sódor Kenneth J. Conant elemzéseire hivatkozik, aki a clunyi apátság régészeti feltárását végezte a 20. század első felében. Az apátság jelenkori kutatása részben meghaladta Conant eredményeit, de ezek legnagyobb részt nem a második és harmadik templomra vonatkoznak.

${ }^{98}$ Sódor 1978a 8. A diagon Bradford-on-Avon, Romanmotier és Anzy-le-Duc templomán is kimutatható.

${ }^{99}$ Vitruvius müve 11. századi felhasználásának további példája a hildesheimi Szent Mihály-templom (1010-1122), amelynek építésénél Bernhard püspök bizonyítottan használta a Goderammus-féle Vitruviusmásolatot, a Harleinaus kódexet. Hajnóczi 1996. 247.

${ }^{100}$ Forster Irattár K133/2; Csemegi 1953. 14-15.

${ }^{101}$ Szakál 1977. 101; Csemegi 1953. 17. Csemeginél további magyar példák a triangulációra: Börzsöny, Ócsa, Felsőörs, Egregy, Lébény, Deáki, Harina, Kerc.
} 
Csemegi szerint a hexagramm ősi asztrálszimbólum jelentése a világosság és az örök élet, ami védelmet nyújt az elmúlás és a gonosz ellen. ${ }^{102}$ Bajelhárító szerepe miatt lehetett a különböző keresztény és pogány népek (kopt, örmény, grúz, avar, gót) kedvelt motívuma, nemcsak az épületalaprajzok, hanem az ornamentika eszköztárában is. ${ }^{103}$ Ezt a hagyományt örizhették a nyugat-európai $12-13$. századi hatszög alaprajzú keresztelőkápolnák és medencék is, például a poitieri Szent János-templom keresztelőkápolnája vagy a Rajna-vidék keresztelömedencéi. ${ }^{104}$ Az építészet szimbolikus tartalmának fontosságát a romanikában a 12. századi teoretikusok írásai is bizonyítják. ${ }^{105}$

A tervezési elvek további érdekessége a középkori épületeken alkalmazott optikai korrekciók kérdése, amelyet Gerevich Tibor ${ }^{106}$ és Szakál Ernő ${ }^{107}$ vetett fel. Szakál szerint a jeruzsálemi Szent Anna-templom (1130-as évek) szentély felé szükülő hajófalai és oszlopközei a tér perspektivikus hatását hivatottak növelni. Feltételezése szerint a vértesszentkereszti apátsági templom oszlopközei hasonló okokból tágulnak a szentély irányába. Gerevich szerint az optikai korrekciók - pl. a hajóboltozatok magasságának csökkenése a szentély felé - inkább a francia és olasz középkori építészetre voltak jellemzők, szemben a német területen tapasztalható túlszabályozott szerkesztettséggel. Gerevich és Szakál meglátásai csupán felvetik annak a kérdését, hogy a középkori építészetnek voltak-e illuzionisztikus eszközei, ahogyan az ókorban, vagy később a reneszánszban és barokkban. A kérdés kutatása a jövő feladata lehet, ekképpen nemcsak az említett példák, hanem továbbiak elemzésével. Az alaprajzi korrekciókkal szemben valószínübbek a homlokzaton alkalmazottak. Szakál Ernő saját kutatásaiból a bélapátfalvai apátsági templom északi homlokzatának körablakát említi, mely a felmérés tanúsága szerint valójában függőlegesen nyújtott ellipszis alakú. A jelenséget Szakál a magasság miatti perspektivikus torzulás kiküszöbölésével magyarázta.

\footnotetext{
${ }^{102}$ A Mezopotámiából átvett hatszögmotívum Jahve szimbóluma volt a zsidók körében, akiknek köszönhetően egész Európában elterjedt. A középkorban bajelhárító szerepe miatt lehetett népszerű. Csemegi 1960. 332.

${ }^{103}$ Csemegi Közép-Európa viszonylag nagyszámú hatszögü épületét Kaukázus-vidéki kapcsolatokra vezette vissza. Erről tanúskodik a tarnaszentmáriai templom déli homlokzatán lévő apotropaikus relief is. Csemegi 1960. 345 .

${ }^{104}$ Csemegi 1960. 336. 26. lábjegyzet.

${ }^{105}$ „Ezt a házat kőre alapozzák; az egyház is Krisztusra, mint erős kősziklára alapul. Négy fallal szökik magasba, az Egyház is a négy evangélium által nő az erények magasába. A ház szilárd kövekből épül, az egyház is a hitben és tettben erősekböl áll. A köveket habarcs tartja össze, a hívőket is a szeretet köteléke füzi egybe. (...) Az átlátszó ablakok, amelyek a vihart kizárják, és a fényt beengedik, az egyházatyák, akik ellenállnak az eretnekség zavarának, és az egyházba árasztják a tanítás világosságát. Az üveg az ablakokban, melyen keresztül a fénysugár bevetődik, az egyházatyák elméje, amely a mennyei dolgokat rejtélyként, mintegy tükrön át szemléli. Az oszlopok, melyek a házat tartják, a püspökök, akik az egyház épületét igaz életükkel magasba emelik. A házat összefogó gerendák a világ fejedelmei, akik összetartván az egyházat, erősítik azt. A tető cserepei a harcosok, akik védik az egyházat a pogányoktól és ellenségeitöl." (Honorius Augustodunensis: A lélek ékköve 2. könyv, 129-131. fejezet, 1130 körül) fordítás Marosi 1969. 33. Hajnóczi 1996. 253.

${ }^{106}$ Gerevich 1910. 60.

${ }^{107}$ Szakál 1977. 101.
} 
Ahogyan az ókeresztény építészetben, úgy a romanikában is fontos volt egyes kultikus épületek mintaadó szerepe. A 11. században a cambrai bazilika ${ }^{108}$ és a paderborni apátság ${ }^{109}$ a középkori források bizonysága szerint méreteivel a jeruzsálemi Szent Sír-templomot követte.

\section{GÓTIKA}

A gótika építészetével kapcsolatban a szakirodalom egyöntetüen hangsúlyozza a geometriai alapidomokra épülő szerkesztőhálók alkalmazásának fontosságát. Ezekre vonatkozóan immár korabeli rajzi és írásos források alapján is képet alkothatunk. A kutatók véleménye elsősorban abban tér el, hogy melyek voltak a legmeghatározóbb rendszerek, illetve kimutatható-e valamely rendszer elsődlegessége egyes korszakokra, földrajzi területekre, illetve mühelyekre vonatkozóan.

A gótikus építészet forradalmát és elterjedését a szerkezeti és alaktani újítások mellett gazdasági és társadalmi változások együttes hatása eredményezte. A 11-12. századra kialakuló városiasodással párhuzamosan megélénkült a kelettel folytatott kereskedelem, amelynek következtében az arab és antik tudomány széles körben terjedt el Nyugat-Európában. ${ }^{110}$ Ez nagy hatással volt az építészet elméletére és segédtudományaira is. A geometria Eukleidész módszereivel gazdagodott, a matematika fejlödésének pedig ékes példája Leonardo Bonacci (Fibonacci) Liber Abaci címú müve (1202), amelyben létrehozta az aranymetszéssel jellemezhető Fibonacci-sort. Az építészeti tervezés szempontjából is fontos, hogy a számarányokat a zene arányaival feleltették meg (1:1 unisono, 1:2 oktáv, 2:3 kvint, 3:4 kvart stb.). ${ }^{111} \mathrm{Az}$ antik tudományok hatása a megismerés módjának szemléletbeli változását eredményezte: a hiszem, mert lehetetlen elvét megingatta az empirizmus, a tapasztalás általi új tudás megszerzése. ${ }^{12} \mathrm{Az}$ új ismeretek és a keresztény dogmák között feszülő ellentét felismerése miatt a tudományok müvelése egyre inkább kikerült a kolostorok fennhatósága alól, s ez végső soron az építés iparszervezetének átalakulásához is vezetett. A városok fejlődésével szükségessé váló - továbbra is elsősorban egyházi - építkezések száma megnövekedett, mind a polgárság erejét is reprezentáló katedrálisok alapítása, mind a városi szerzetesrendek tevékenysége folytán.

${ }^{108}$ „Ezért a cambrai-i sír fölé helyezett márvány is 7 láb hosszú, mivel ugyanilyen hosszúságú az a hely, ahová az Úr testét helyezték.” (12. századi feljegyzés) fordítás Marosi 1969. 66.

${ }^{109}$ „a püspök (Meinwerk) tehát (...) kívánván templomot építeni, Wino helmarshauseni apátot, akit városa szerzeteseinek élére állított, magához hívatta, és Jeruzsálembe küldvén őt, megbízta, hogy hozza el neki a Szent Sír-templomának mértékeit.” (12. századi feljegyzés) fordítás Marosi 1969. 66.

${ }^{110} \mathrm{Az}$ ókori műveltség iránti érdeklődés olyan mértéket öltött, hogy ezt az időszakot „12. századi reneszánsznak" is nevezzük. Sódor 1974. 48; továbbá Charles Homer Haskins: The Renaissance of the Twelfth Century. Harvard University Press, Cambridge 1927.

${ }^{111}$ Sódor 1974. 49. Szent Ágoston a zenét és az építészetet együttesen a „számok testvéreinek” nevezte. A zene és az építészet viszonya Henszlmann arányelméletében is fontos szerepet játszott. Henszlmann 1864. 46; Henszlmann 1860. 18-20.

${ }^{112}$ Sódor 1978a 12. 
A szerzetesi mühelyek sem a nagyszámú megrendeléseknek, sem az új építészeti problémáknak nem tudtak megfelelni. ${ }^{113}$ A szakmai tudás a laikus mesterek körében hódított teret, megszerzésének új intézménye pedig az egyetem lett. ${ }^{114} \mathrm{~A}$ szakmagyakorlás elvilágiasodása következtében a valóban minőségi építőtudás felértékelődött, védelmére létrejöttek az építőpáholyok és a céhek. ${ }^{115}$ Ezek a szervezetek szigorú szabályozással és titoktartással védték a tagok érdekeit. ${ }^{116}$ A páholyok által felhalmozott tudás az empirikus úton kifejlesztett szerkezeti és formai ismeretekből állt, ami elsősorban a tervezési módszerekben mutatkozott meg.

A téregységesítés és a reprezentáció igénye a katedrálisok egyre merészebb méreteiben nyilvánult meg, ezért a gótikus építészet legfontosabb újítása a szerkezeti forradalom (csúcsíves, bordás boltozatok és a támívek rendszere) és a vázasság volt. ${ }^{117}$ A kora középkori és romanikus építészetet többféle tervezési módszer határozta meg, de említettük, hogy a geometrikus (háromszöges vagy négyzetes) szerkesztőhálók alkalmazását több kutató is kifejezetten a gótika jellegzetességének tartotta. ${ }^{118}$ Ennek oka az lehetett, hogy a geometrikus szerkesztések szerepe a 12. században valóban megnőtt. A szerkezet összetettségéből fakadó, alapvetően empirikus statikai, szilárdságtani megfontolások a tervezési folyamat új szempontjai lettek, ez az építőpáholyok gyakorlatában a szerkesztőmódszerek ökölszabályaiban öltött testet. ${ }^{119}$ A geometria szerepének megnövekedését mutatja az is, hogy a tervezésről fennmaradt csekély számú írott és rajzos középkori forrás legnagyobb része a gótika korából származik, és föként szerkesztési módszerekről tudósít. A fennmaradt ábrák közös sajátossága, hogy sem kótákat, sem a tervezésre utaló segédvonalakat nem tartalmaznak, ami részben a mühelyek fent leírt titoktartásával magyarázható. ${ }^{120}$ A másik lehetséges ok a tervezésnek és kivitelezésnek a romanika vizsgálatánál már

\footnotetext{
${ }^{113}$ Sódor 1978a 13; Gerevich 1910. 47.

${ }^{114}$ Bologna 1088, Oxford 1096, Párizs 1150, Modena 1175, Cambridge 1208, Salamanca 1222, Padova 1222, Nápoly 1224, Siena 1240 stb.

${ }^{115}$ A céhek Olaszországra, Franciaországra, Angliára és Magyarországra jellemzőek, míg a páholyok Németországra. Gerevich 1910. 48, 73. E két iparszervezeti forma területi eloszlása azonban bizonyosan árnyaltabb volt, sőt valószínü, hogy a céhek párhuzamosan müködtek a nagyobb templomok építésére szervezödő építőpáholyokkal. Ezt támasztja alá az épitőpáholy szó megfelelője az idegen nyelvü terminológiában: loge de maçonnerie, freemasons lodge, Bauhütte. Csemegi 1953. 28.

${ }^{116}$ A mühely szakmai titkainak fontosságát több formaság is mutatja: jelbeszéd, a felszabaduló legények titoktartási esküje vagy a munkaterembe való belépés titkos kopogáshoz és jelszóhoz kötése. Gerevich 1910. 53; Szakál 2007. 83.

${ }^{117}$ Gerevich 1910. 55.

${ }^{118}$ Forster Irattár K133/2; Csemegi 1953. 14-15.

${ }^{119}$ Csemegi 1953. 26. Horváth 1935. 25 szerint a páholyok geometriai eljárásaiban a statikai és esztétikai tudás leképeződése érhető tetten.

${ }^{120}$ Csemegi 1953. 27. Matthes Roriczer könyveiben többször javasolta a szerkesztővonalak kitörlését rajzolás közben, például: „Ha azokat a vonalakat, amelyekre nincsen szükségünk, és melyeket csak a szerkesztéshez használtunk, eltávolítod, akkor annak olyan lesz az alakja, mint az alábbi ábra." (Geometria deutsch 14861490) fordítás Sódor 1982. 383. Ez a gyakran ismételt mozzanat a mühelyt jellemző diszkrécióra is visszavezethető, de valószínü, hogy a szerkesztővonalak törlésével csupán a rajzok tisztázása volt a cél.
} 
ismertetett összefüggése, hogy a tervezett alaprajzi kompozíciót a valóságban néhány helyszíni méret segítségével újraszerkesztették.

A hazai szakirodalom természetesen komoly figyelmet szentelt e korabeli források elemzésének, és többen kutatták a bennük megjelenő szerkesztési módszerek alkalmazásának lehetőségét a vizsgálódásuk tárgyát képező hazai emlékek esetében. Érdemes ezért röviden áttekinteni a leggyakrabban idézett müveknek a tervezési módszerek szempontjából fontos tanulságait.

A középkori mühelyekben folyó munkáról tudósító legkorábbi fennmaradt forrás Villard de Honnecourt picardiai építőmester 1230-as években készült rajzgyüjteményes könyve. Rendeltetésének kérdése a magyar kutatókat is foglalkoztatta, mert ez a mü egyedüliként tájékoztat bennünket századának tervezési technikáiról. Sódor Alajos és Szakál Ernő szerint a mester mühelye számára készítette a könyvet, ${ }^{121}$ ami lehet, hogy útinaplónak indult, mivel szerzője a kor szokásának megfelelően több város templomának építésén dolgozott (Vaucelles, Cambrai, Reims, Laon, Chartres, Lausanne, Kassa), és az ott látott újdonságokat füzetében rajzosan és szövegesen is megörökítette. ${ }^{122}$ A könyv bevezetője azonban már arra utal, hogy az összegyüjtött ábrák útmutatóként közhasználatra, akár oktatási célt szolgáltak: „Villard de Honnecourt üdvözöl benneteket, és kéri mindazokat, akik azokkal az eszközökkel fognak dolgozni, melyek ebben a könyvben találhatók, hogy imádkozzanak lelkéért, és emlékezzenek meg róla. Mert ebben a könyvben nagy útmutatás található a kőmüvesség nagy mesterségéről és az ácsmesterség szerkezeteiről. És megtaláljátok a rajzolás mesterségét, a vonalakat, ahogyan ezt a geometria müvészete megköveteli és tanítja" (2. lap). ${ }^{123}$ Erre enged következtetni az is, hogy a lapokon további ismeretlen mesterek rajzai különböztethetők meg Villard de Honnecourtéitól, a bejegyzések tanúsága szerint pedig még a 15. században is használták. ${ }^{124}$ Sódor Alajos szerint az ilyen mühelykönyvek a középkor második felében általánosak voltak. ${ }^{125}$ Marosi Ernő szerint feltételezhető, hogy a két későbbi (de még 13. századi) mester, akik az eredeti rajzok egy részét (39-41. lap) kikaparva geometriai receptekkel ${ }^{126}$ egészítették ki a müvet, Villard páholytestvérei lehettek. ${ }^{127}$ A hét fejezetre osztható 66 lapból álló vázlatkönyv valóban betekintést nyújt abba, hogy a középkori építőmühelyek milyen típusú feladatokkal foglalkoztak. Az építészeti vonatkozású példákon és szerkesztéseken kívül számos figurális ábrázolást, kisplasztika vázlatát, szobrászati kompozíciót, különböző ácsszerkezeteket, állványzatokat, gépeket láthatunk. Villard

${ }^{121}$ Sódor 1978a 14; Szakál 2007. 91.

${ }^{122}$ „Sok vidéken voltam, mint ebben a könyvben láthatjátok...” (18. lap) fordítás Marosi 1969. 203.

${ }^{123}$ Fordítás Marosi 1969. 203.

${ }^{124}$ Sódor 1978a 15-16; Marosi 1969. 203.

${ }^{125}$ Sódor 1978a 14.

${ }^{126} \mathrm{Az}$ elméleti bizonyításokat nélkülöző, pusztán szerkesztési lépéseket felsoroló útmutatásokat a szakirodalomban elterjedt receptnek nevezhetjük. Strommer 2008. 11.

${ }^{127}$ Marosi 1969. 203. Hans R. Hahnloser M2 és M3 nevekkel különböztette meg a későbbi bejegyzések szerzőit. (Hans R. Hahnloser: Villard de Honnecourt: Kritische Gesamtausgabe des Bauhüttenbuches ms. fr. 19093 der Pariser Nationalbibliothek. Bécs 1935.) 
az ember- és állatrajzok egy részébe háromszögeket, négyszögeket és ötágú csillagokat rajzolt. Lehetséges, hogy csupán a nehezebben megrajzolható ábrák készítésére kínált útmutatást (35-36. lap, a 38. lapon négyzethálót alkalmazott), figyelemre méltó azonban, hogy párhuzamot vont az organikus formák és az absztraktabb síkidomok között, sőt néhány szimmetrikus kompozíciót kifejezetten a geometriára épített (37-38. lap) (9. ábra).

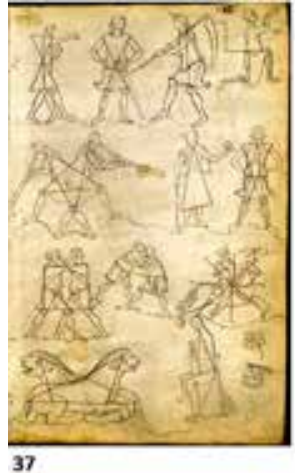

9. ábra. Villard de Honnecourt vázlatkönyvének 37., 38., 39. és 63. lapja forrás: http://classes.bnf.fr/villard/feuillet/)

A vázlatkönyvben található több épületszerkezeti rajz (saját munkák alapján vagy meglévő épületekről) rámutat, hogy mik voltak a 13. század építészetének nagy körültekintést és tapasztalatot igénylő tervezési feladatai. ${ }^{128}$ Ilyen például a kápolnakoszorús francia szentély (félköríves és egyenes záródású kápolnák váltakozásával), amely több helyen szerepel alaprajzi és homlokzati vetületben (28-29., 33., 60-61. lap), a rózsaablak és más mérmüves ablakok (20., 30. lap), pillérkötegek, bordaprofilok (63. lap, 8. ábra) vagy a trifórium (62. lap). A 13. század folyamán a páholytársak a mühelykönyvet a tervezéshez és kivitelezéshez szükséges megoldásokkal egészítették ki, amelyek között szerepelt például a kolostorkerengő kitüzése, amelyhez derékszög rajzolása szükséges ${ }^{129}$ egy körszelet középpontjának és átméröjének megrajzolása ${ }^{130}$ és a jó arányú kerengő folyosóinak megszerkesztése, amihez a négyzetbe fele akkora négyzetet kell rajzolni ${ }^{131}$ (8. ábra). Sódor rámutatott, hogy Villard

\footnotetext{
${ }^{128}$ Sódor 1978a 15.

${ }^{129}$ „Ekképpen helyezzük el egy kerengő négy sarkát ólom és vízmérték nélkül” (39. lap) fordítás Marosi 1969. 207.

${ }^{130}$ „Ekképpen vesszük fel a vastagságát egy oszlopnak, amelyet nem látunk egészen. (...) Ekképpen található meg egy körszelet középpontja" (39. lap) fordítás Marosi 1969. 206.

${ }^{131}$ „Ekképpen csinálunk egy kerengöt, melynek ugyanakkorák a folyosói, mint a kertje” (39. lap) fordítás Marosi 1969. 206. Hasonló geometriai eljárás továbbá: „Ekképpen osztunk fel egy követ úgy, hogy mindkét fele négyzet" (39. lap) fordítás Marosi 1969. 208. A két feladat közös szerkesztése, a négyzet felezése a későbbi, 15. századi forrásokban is különös jelentőséggel bírt. A négyzet oldalfelezésén alapuló eljárás az ókorból eredeztethetö, Vitruvius a földmérés eszközeként írta le. A 10. században II. Szilveszter pápa is említette Geometria incertis auctoris címü mủvében. Sódor 1978a 19.
} 
de Honnecourt vázlatkönyve annak is bizonyítéka, hogy a 13. századi mühelyekben dolgozó mesterek a geometriai tételek elméleti belátása nélkül alkalmazták a szerkesztéseket. Habár Eukleidész műveiről ekkorra már széles körben tudtak (ennek nyomai látszanak a későbbi mesterek útmutatójának logikai felépítésében), ezekből az építőiparba csak a gyakorlatban szükséges szerkesztések lépései, mint receptek származtak át. ${ }^{132}$

Villard de Honnecourt 1235 körüli magyarországi látogatása - amit a vázlatkönyv bejegyzései bizonyítanak ${ }^{133}$ - több kutató szerint is hatással volt a magyar kora gótika kialakulására. A 30. lapon látható padlómotívum alapján Horváth Henrik azt feltételezte, hogy a pikárdiai mester megismerte a dunántúli régiót, a kassai Szent Erzsébet-templom építésében való közremüködése pedig stíluskritikai alapon is feltételezhető. ${ }^{134}$ Marosi Ernő és Szakál Ernő szerint a mühelykönyv egyik rajzával hozható összefüggésbe a pilisi ciszterci apátságnak és Merániai Gertrúd síremlékének francia stílusrokonsága is. ${ }^{135}$ Villard de Honnecourt magyarországi útja mindenesetre hatással lehetett hazánk 13. századi építészetére és tervezési módszereire is.

Villard mühelykönyvéből is látható, hogy a középkori szerkesztések legfontosabb alapidomai a szabályos háromszög és a négyzet voltak, amelyekből a legkülönfélébb módon (sokszorozással, elforgatással stb.) készíthettek szerkesztési hálókat vagy akár kész kompozíciókat, de számos példa mutatja, hogy az idomok egyedül is lehettek a rajzok alapjai. A háromszög és a négyszög fontosságát szimbolikus értelmezésük is mutatja, ahogyan azt a 12. századi teológus, Thierry de Chartres felfogása is mutatja: az egyenlő oldalú háromszög a Szentháromságot, a négyzet pedig az Atya és a Fiú kapcsolatát testesítette meg. ${ }^{136}$ Ahogyan Villard de Honnecourt is egyaránt használta a háromszöges és a négyszöges rajzolást, úgy valószínűleg ezek a középkor minden építészének eszköztárában szerepelhettek, sőt gyakran egy épület szerkesztésében több idom együttes használata fedezhető fel. ${ }^{137}$ Franz Ržiha kőfaragójelekre vonatkozó elmélete ${ }^{138}$ ezzel szemben arra utal, hogy az alapidomok mühelyekhez rendelhetők. Eszerint a négy német fópáholyhoz egy-egy geometriai idom tartozik, ami a kőfaragójelekben is megmutatkozik: a strasbourgi páholy anyakulcsa a négyzet (quadratura), a kölni páholyé a háromszög (trianguláció), a bécsié négykaréjos (Vierpas), Berné pedig háromkaréjos (Dreipas) forma (2. ábra). Ennek az el-

${ }^{132}$ Sódor 1978a 15-16.

${ }^{133}$ „Amikor ezt lerajzoltam [reimsi ablak], mert ezt szerettem leginkább, Magyarország földjére küldtek.” (20. lap) fordítás Marosi 1969. 203.

${ }^{134}$ Horváth 1935. 70-72.

${ }^{135}$ Szakál 2007. 91; Marosi 2008. 14; Entz 1973. 58. Villard de Honnecourt valószínüleg a szülőfalujához közeli vaucelles-i ciszterci apátsági mühely tagja volt, és magyarországi útja is a rend - magyarországi első és legjelentősebb képviselője, a pilisi apátság - közvetítésével történhetett, amelyre a számos alaktani stíluskapcsolat mellett Meráni Gertrúd szarkofágja is utal. Bővebben Gerevich 1971.

${ }^{136}$ Hajnóczi 1996. 254.

${ }^{137}$ Forster Irattár K133; Gerevich 1910. 60 szerint előfordult, hogy a mértékegység sem volt egységes a teljes épületen, ami föleg Franciaországra és Olaszországra jellemzö.

${ }^{138}$ Franz Ržiha: Studien über Steinmetzzeichen. Bécs 1883. A magyar szakirodalomban: Frőde 1900; Horváth 1935; Várnai 1974. 
méletnek több vitatható pontja is van, amire már a magyar kutatás is felhívta a figyelmet. ${ }^{139}$ Ržiha elméletének is köszönhetö azonban, hogy legtöbb kutató szerint a középkori épületekben felfedezhető geometriai szabályosságok az építők származására, mühelykötődésére utalhatnak. ${ }^{140}$ Ez azonban csak abban az esetben igaz, ha valamilyen konkrét, különleges szerkesztés azonosságát mutatjuk ki, a négyzetes és háromszöges szerkesztés önmagában nem tekinthető mühelysajátosságnak.

Csemegi József a szentélykörüljárós csarnoktemplomok fejlődési vonalában Hans Stethaimer, burghauseni, 15. századi építész munkásságához kötötte a templomhajó teljes szélességének és a főhajó pillérközeinek hatszög általi meghatározását. ${ }^{141}$ Hoppe László saját helyreállítási munkái során állapította meg, hogy a csarodai és vámosatyai, 13. század végi - 14. század eleji templomok alaprajzi szerkesztése csaknem minden részlet tekintetében megegyezik (Hajó és szentély kitüzése, falvastagság megállapítása stb.). ${ }^{142}$ Ezek a geometria alapján történő mühelyazonosítás jó példái, mert a tervezési módszerek a felsorolt példák mindegyikében több lényeges ponton azonosak. Ezzel szemben nem tekinthetők helytállónak Czagány István eredményei, aki a budavári emlékanyag geometriai vizsgálatából vont le messzemenő következtetéseket a mesterekre vonatkozóan. Az általa kimutatott szerkesztések egyszerü triangulációs vagy quadraturás alapeljárások, amelyeket valószínűleg széles körben alkalmaztak a középkorban. ${ }^{143}$ Mindazonáltal Czagány egyes észrevételei figyelemre méltóak, ilyen például a Mária Magdolna-torony egyértelműen quadraturás szerkesztőhálója, amelyet a ržihai elmélet alapján a strasbourgi páholyhoz kötött. ${ }^{144} \mathrm{Ez}$ az alaprajzi séma azonban feltünően hasonlít a bécsi Szent István-dóm északi tornyának Csemegi által bemutatott egykorú rajzára is. ${ }^{145} \mathrm{~A}$ bécsi kapcsolatokat támasztja alá, hogy Czagány szerint a Mária Magdolna-torony 1588-ban készült délkeleti vendégtámpillére a Szent István-dóm hosszháztámpillérével mutat rokonságot. ${ }^{146}$ A bécsi támpillér szintén egykorú rajzát Csemegi József a csütörtökhelyi Zápolya-kápolna (1473) támpilléreivel és a bázeli mintalap hasonló quadraturás támpillérrajzával állította párhuzamba. ${ }^{147}$

\footnotetext{
${ }^{139} \mathrm{Az}$ elmélet alapján besorolt kőfaragójelek a legtöbb esetben nem állnak összhangban a stíluskritikai alapon megállapított műhelykapcsolatokkal. További problémát jelentenek a prágai páholy mesterjegyei, amelyekben szintén a bern-zürichi háromkaréjos idom a leggyakoribb. Az is megkérdőjelezhető, hogy a kőfaragójeleket valóban előszerkesztés után vésték a kövekre. Horváth Henrik megkérdőjelezte a karéjos anyakulcsok önállóságát is, hiszen ezek a háromszög és négyzet íves változatai, és igen csekély számban fordultak elö. Horváth 1935. 23. Csemegi József többek között kifogásolta, hogy az anyakulcsok gyakran nem egyeznek meg az adott páholynak tulajdonított épületek geometriájával. Azt is megkérdőjelezte, hogy a nagyszámú középkori mühely kőfaragójeleit összesen négy alapidommal meg lehetne határozni. Csemegi 1936. 17.

${ }^{140}$ Forster Irattár K133/2; Csemegi 1935, 1937, 1953; Várnai 1974; Czagány 1978, 1985; Hoppe 1993.

${ }^{141}$ Csemegi 1935, 1937.

${ }^{142}$ Hoppe 1993. 369.

${ }^{143}$ Czagány 1978, 1985.

${ }^{144}$ Czagány 1985. 409, 412 szerint a 15 . századi strasbourgi $45^{\circ}$-os szerkesztés Regensburgon és Bécsen át vándorolt Budára.

${ }^{145}$ Csemegi 1936. 4-7.

${ }^{146}$ Czagány 1985. 412.

${ }^{147}$ Csemegi 1953. 19, 46-47.
} 


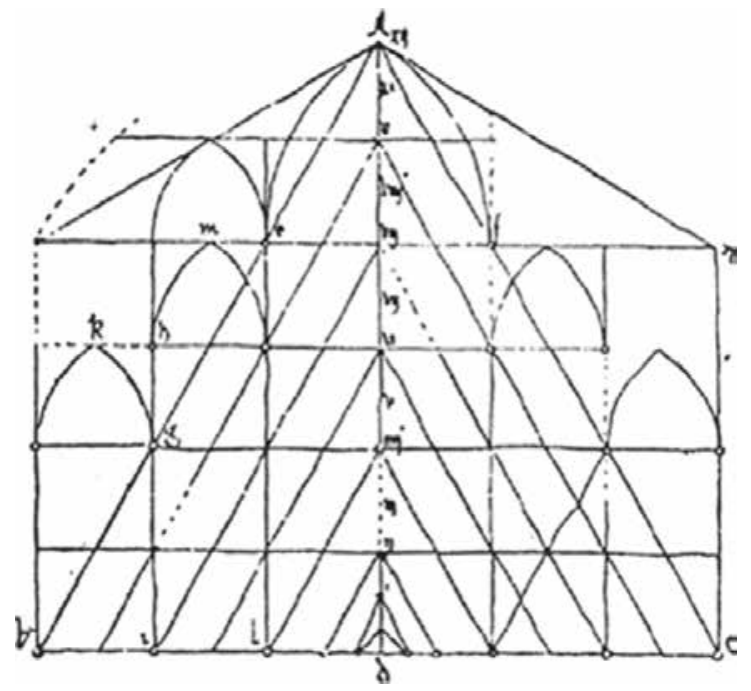

10. ábra. Stornalocco vázlata a milánói dóm keresztmetszetére, 1391 (forrás: Guzsik 1994c 56)

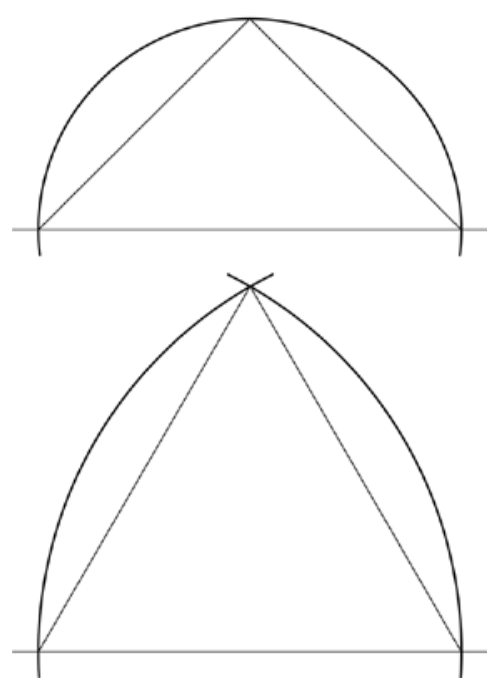

11. ábra. Félköríves és csúcsíves szerkesztés sémája (forrás: szerzők rajza)

A középkori építészetben állandóan jelenlévő háromszög és négyszög általános, mühelytől független használatát tanúsítják a milánói dóm 1386-ban megkezdett építkezésének évkönyvei. A templom tervezési kérdéseit érintő, 1388 és 1401 között lezajlott vita több napirendi pontjából fontos következtetéseket vonhatunk le a tervezést meghatározó tényezőkről. A templom méretezési hibái már 1388-ban szakértők bevonását tették szükségessé, akik közül az olasz Gabriele Stornalocco és a francia Jean Mignot képviselték a legmarkánsabb véleményt. ${ }^{148}$ Az első vitás kérdés az volt, hogy a templomhajó magasságát a négyzet vagy a háromszög alapján határozzák meg, ${ }^{149}$ ami e két eljárás párhuzamosságára, bizonyos szempontok szerinti felcserélhetőségére vall. A milánói dóm esetében a döntést statikai megfontolásoktól tették függővé, de később a gazdasági szempontok alapján módosították a terveket. ${ }^{150}$ Stornalocco a keresztmetszet megszerkesztéséhez a szabályos háromszöget javasolta, ahogyan azt vázlata is mutatja ${ }^{151}$ (10. ábra). Mignot 1400-ban élesen bírálta

${ }^{148}$ A vitában részt vett 1391-ben egy kölni mester, majd 1392-ben a gmündi Heinrich Parler. 1394-95-ben Ulrich von Ensingen, ulmi dómépítő mester, 1399-ben pedig a Párizsból érkező Jean Mignot készített szakvéleményt, de a milánóiak a gyakorlatban egyikük javaslatait sem fogadták el. Egyedül a piacenzai Gabriele Stornalocco (matematikus) véleménye érvényesült 1392-ben, akire Jean Mignot mint „valamely tudatlanok”-ra utalt az épület hibáinak számbavételénél. Marosi 1969. 209.

${ }^{149}$ Forster Irattár K133; „Vajon a templomnak magának, nem számítva mértékébe a felépítendő kupolát, a négyzetig vagy a háromszögig kell-e emelkednie?” (1392) fordítás Marosi 1969. 210.

${ }^{150}$ Forster Irattár K133 szerint a milánói dómot először a háromszögnél is magasabbra tervezték, de később a költségek miatt még annak csúcsánál is alacsonyabb lett.

${ }^{151}$ A legmerészebb javaslat Antonio di Vicenzóé volt, aki a négyzetes befoglaló formát ajánlotta. Marosi 1997 a 173. 
Stornalocco döntését, mert a templom tartószerkezeti rendszerét nem találta megfelelőnek a boltozatok fogadására. A négyzet (ad quadratum) és a háromszög (ad triangulum $)^{152}$ közötti dilemma valószínűleg nem csak a főhajó magasságának meghatározására vonatkozott. A két idom (a négyzet fele, a $45^{\circ}$-os háromszög és a $60^{\circ}$-os háromszög) ugyanis a félkörív és csúcsív szerkesztési alapsémáinak is tekinthető, tehát lehetséges, hogy a magasságra vonatkozó, ködösen megfogalmazott kérdés egyúttal a boltozatok formájára is irányult (11. ábra). Ezt támasztja alá Mignot kijelentése: „Ezekről pedig annyit, hogy bizonyára kedvtelésből csinálták valamely tudatlanok, akik azt bizonygatják, hogy a csúcsívek erősebbek, és kisebb nyomásúak, mint a kerek boltozatok, és más dolgok felöl is többet hivatkoztak az akaratra, mint a lehetőségre. (...) Az említett János mester azt mondja, hogy (...) a boltozatok akár csúcsívesek, akár kerekek, semmivel sem kevésbé nagy a nyomásuk és a súlyuk."153

A milánói dómépítkezés évkönyvei arra is felhívják a figyelmünket, hogy a gótikus építészeti tervezés eszköztárához a geometriai szerkesztések mellett továbbra is hozzá tartoztak az egyszerü számarányok is. Lehetséges, hogy ezeknek egykor erős szimbolikus jelentése nem veszett el teljesen, de valószínü, hogy szerepükben a statikai megfontolások kerültek előtérbe. Mignot szakvéleményében a dóm támpilléreit túl kicsinek találta a szerkezeti terhek fogadására, mert szerinte azoknak háromszor akkorának kellett volna lenniük, mint a belső pilléreknek. ${ }^{54}$ A párizsi mester itt egy olyan ökölszabály 14. század végi létezését bizonyította, amit valószínűleg saját építészeti munkái során, tapasztalati úton tanult, vagy mestereitől örököltt. ${ }^{155} \mathrm{Az}$ olaszok a tartószerkezeti kritikára kimerítő szilárdságtani választ adtak: a támpillérek megfelelőek, mert márványból és gránitból készültek, amelyek teherbírása kétszer akkora, mint a francia köveké. ${ }^{156} \mathrm{~A}$ gótika tervezési elvei között tehát bizonyítottan szerepeltek a statika szempontjai, amelyeket Mignot rendkívül fontosnak tartott. A matematikus Stornalocco kijelentésére, amely szerint ,,a geometria tudományának nem kell, hogy helye legyen ezekben [a boltozati formákban], mivel a tudomány egy valami, és a müvészet egy másik” Mignot híressé vált mondatával válaszolt: „ars sine scientia nihil est". ${ }^{157}$ Horváth Henrik szerint ebben a két véleményben Stornalocco haladó gondolkodása és önállósága, míg Mignot konzervatív páholyhagyományokat tisztelő magatartása mutatkozik meg, ${ }^{158}$ de felfogható úgy is, mint a gótikában egyre fontosabbá váló szerkezeti gondolkodás létjogosultságának vitája.

\footnotetext{
${ }^{152}$ A szakirodalomban használatos trianguláció és quadratura elnevezések a milánói vita szóhasználata alapján terjedtek el. Sódor 1978a 18.

${ }^{153}$ Fordítás Marosi 1969. 212.

${ }^{154}$,....az egyház körül körös-körül valamennyi támpillér nem erős, és nem alkalmasak, hogy fenntartsák azt a terhet, amely rájuk nehezedik, mivel egyenként háromszor olyan vastagoknak kell lenniük, mint amilyen vastag egy pillér a templom belsejében" fordítás Marosi 1969. 211.

${ }^{155}$ Csemegi szerint az ilyen ökölszabályok általánosak lehettek. Csemegi 1936. 14.

${ }^{156}$, „...mivel a mi márványunkból és gránitunkból készített, minden oldalán egy ölnyi darab oly erős, mint két ölnyi a franciaországi kövekből...” fordítás Marosi 1969. 211.

${ }^{157}$ Marosi 1969. 212.

${ }^{158}$ Horváth 1935. 67.
} 
Ahogyan a milánói évkönyvek kapcsán is láthattuk, a négyzetes szerkesztést a $45^{\circ}$-os egyenlőszárú háromszög alkalmazásával is azonosíthatjuk. Több magyar kutató is úgy vélte, hogy a különbözö háromszögek középkori alkalmazásában idörendi fejlődés mutatható ki. Az elméletek közös ihletője Georg Dehio véleménye, aki a szabályos háromszöget tekintette a középkori tervezés alapjának. ${ }^{159}$ Horváth Henrik szerint, míg a szabályos háromszög az érett gótikához köthető, a négyzet felét, a $45^{\circ}$-os háromszöget inkább a romanikában használták. ${ }^{160}$ Czagány István a budavári emlékek relatív kronológiájának felállítása során a $30^{\circ}$-os háromszög és szerkesztővonalak alkalmazását a 13 . században, a 45, 60-os rendszerét pedig a 14-15. században feltételezte, illetve a szerkesztések bonyolódását és az alapháromszögek keverését a késő gótikához kötötte. ${ }^{161}$ Az eddig bemutatott középkori források azonban arra engednek következtetni, hogy nem lehet egyes geometriai idomokat kizárólagosan korszakokhoz vagy páholyokhoz kötni.

A trianguláción és quadraturán kívül a középkori tervezők használtak ötszöget és további sokszögeket is, bár Hoppe László szerint problémás szerkesztésük miatt ritkán fordultak elő. ${ }^{162}$ Ezeket az idomokat Csemegi József már a román kori centrális templomok elemzésénél is említette, alkalmazásuk okát szimbolikus jelentésükben látta. ${ }^{163}$ Hoppe szerint a középkori mesterek nem ismerték az ötszög szabályos szerkesztését, csupán közelítő módszereket, de ezek a kitüzési pontatlanság hibahatárán belül maradtak. ${ }^{164} \mathrm{Az}$ ötszög szerkesztésében a Villard de Honnecourt vázlatkönyvében is felsejlö elv tükröződik: a geometriai eljárások gyakorlati céljukon túl nélkülözték az elméleti megalapozottságot. Hoppe szerint az ötszöget ritkán választották alaprajzok tervezésekor, mert kedvezőtlen, bizonytalan térérzetet okoz, de gyakran fordult elő a mérmüves ablakok kompozícióiban, ahogyan azt a soproni Szent Mihály-templom Sedlmayr János által elemzett két hajóablaka (14. század első fele) is mutatja. Sedlmayr szerint a pentagramma alkalmazása a szimbolikával magyarázható, mert ez a forma a démonok elriasztását, az üdvösséget jelentette, de az is elképzelhető, hogy a 14. századi kőfaragó csupán ritka geometriai tudását akarta csillogtatni. ${ }^{165}$ Sedlmayr az allegorikus tartalmat az ötszöggel szorosan összefüggő aranymetszésre is kiterjesztette, amelynek alkalmazására szintén találunk példát a gótikus építészetben: Myskovszky Viktor a bártfai Szent Egyed-templom szentségházának (1470 körül) főbb méretei között mutatta ki. ${ }^{166} \mathrm{Az}$ aranymetszéshez közelítő 5:8 arány gyakran felbukkan a gótikus építészet tervezési módszereiben. Henszlmann

\footnotetext{
${ }^{159}$ Georg Dehio: Ein Proportionsgesetz der antiken Baukunst und sein Nachleben im Mittelalter und in der Renaissance. Strasbourg 1895.

${ }^{160}$ Horváth 1935. 69.

${ }^{161}$ Czagány 1978, 1985.

${ }^{162}$ Hoppe 1995.

${ }^{163}$ Csemegi 1960. 332.

${ }^{164}$ Hoppe 1995. 143. Középkori ötszögszerkesztési módszerek forrásai: Villard de Honnecourt vázlatkönyve, a második mester; Matthes Roriczer: Geometria deutsch; két Bécsben őrzött rajz; Frankfurti mintakönyv; Hans Hammer vázlatkönyve.

${ }^{165}$ Sedlmayr 1992. 22.

${ }^{166}$ Myskovszky 1878.
} 
Imre és Möller István szerint a középkorban használták az ún. egyiptomi háromszöget, amelynek alap-magasság aránya 8:5. ${ }^{167}$ Czagány István a budavári anyag elemzésekor szintén az 5:8-as arányt találta az Úri utca 38. számú ház kapualjának déli ülöfülkéiben. ${ }^{168} \mathrm{Az}$ aranymetszés mellett más aránypárok is megtalálhatók a gótikus épületekben, amelyek hátterében lehetnek a már említett statikai ökölszabályok, vagy az építészet és a zene arányainak azonosságai, de valószínű, hogy a számok a középkor második felére sem veszítették el szimbolikus jelentésüket. Csemegi József tanulmánya alapján a romanikára jellemző számarányos tervezési mód a szászországi késő gótikus templomok fejlődési vonalában is kimutatható, amelybe az egri várszékesegyház 3:4:6 arányú alaprajzi rendszere is beleilleszkedik. ${ }^{169}$ Gerevich Tibor a késő középkori számszimbolikát szintén a német templomok sajátosságának tartotta. ${ }^{170}$

A magyar kutatástörténetben egyébként is gyakran találkozunk olyan meglátásokkal, hogy bizonyos tervezési módszerek főleg a kései gótikában kifejezetten német sajátosságoknak tekinthetők, amit az egykorú forrásokban előforduló utalások is alátámasztani látszanak. Cesare Cesariano (12. ábra), itáliai teoretikus 1521-ből származó Vitruvius-fordításában a milánói dómról azt írta, hogy „,német szimmetriában” készült. ${ }^{171} \mathrm{~A}$ bolognai San Petronio-templomban, ahol a 16. század végén a milánói vitához hasonlóan a hosszház magasságának meghatározása volt problémás kérdés, a kortársak (Francesco Terribilia vezető építész ellenében) „német szabályokra" hivatkozva a szabályos háromszöget javasolták. ${ }^{172}$ Czagány István ezzel szemben a négyszöges szerkesztést tartotta német eredetünek a budavári emlékek vizsgálata során. ${ }^{173}$ Látható tehát, hogy a német tervezőgyakorlatra egyaránt jellemző lehetett a trianguláció, a quadratura és az arányszámok alkalmazása is, ami megerösíti, hogy a nemzetekhez, területekhez köthető szerkesztési módok egyértelmü megállapítása igen nehéz. (A két alapidomra a francia építészetből is könnyedén említhetünk példákat: a párizsi Notre Dame főhomlokzata négyzetek és arányszámok segítségével, ${ }^{174}$ a Sainte Chapelle tervei pedig szabályos háromszöggel szerkeszthetők meg. ${ }^{175}$ )

${ }^{167}$ Forster Irattár K123/6; Henszlmann 1880. 4 szerint 8:5 az aránya a gízai piramisoknak és a Clunyben alkalmazott csúcsívnek is.

${ }^{168}$ Czagány 1978. 165.

${ }^{169}$ Csemegi 1935. 15-17; Csemegi 1953. 17. Például München, Frauenkirche; Nürnberg, Szent Lőrinctemplom; Weissenburg, Szent András-templom; Schneeberg, Szent Farkas-templom.

${ }^{170}$ Gerevich 1910. 58. Például a regensburgi domonkos templom méreteit a 3, a 8 és ezek kombinációi, pl. 3+8/2=7; a marburgi Szent Erzsébet-temploméit a 3, a 4, a 3x4=12, stb.; az altenstadti plébániatemploméit pedig a 3 és a 10 .

${ }^{171}$ Csemegi 1935. 9.

${ }^{172}$ Csemegi 1953. 24; a keresztmetszet triangulációs szerkesztését igazolja Guzsik 1994c 58. LIV. tábla 2. e. ábrája is.

${ }^{173}$ Czagány 1985. 407-410.

${ }^{174}$ Sódor 1974. 46.

${ }^{175}$ Csemegi 1953. 16. 
A quadratura német eredetének hipotézisét valószínűleg az erősítette, hogy a 15. század végétől több geometriai témájú német mühelykönyvet is ismerünk, amelyek minden addiginál több információt árulnak el a középkori tervezésről. Matthes Roriczer fiatoronykönyvecskéje (Büchlein von der Fialen Gerechtigkeit, 1486), wimpergakönyve (Wimpergbüchlein, 1486-1490) és Geometria deutsch címü müve

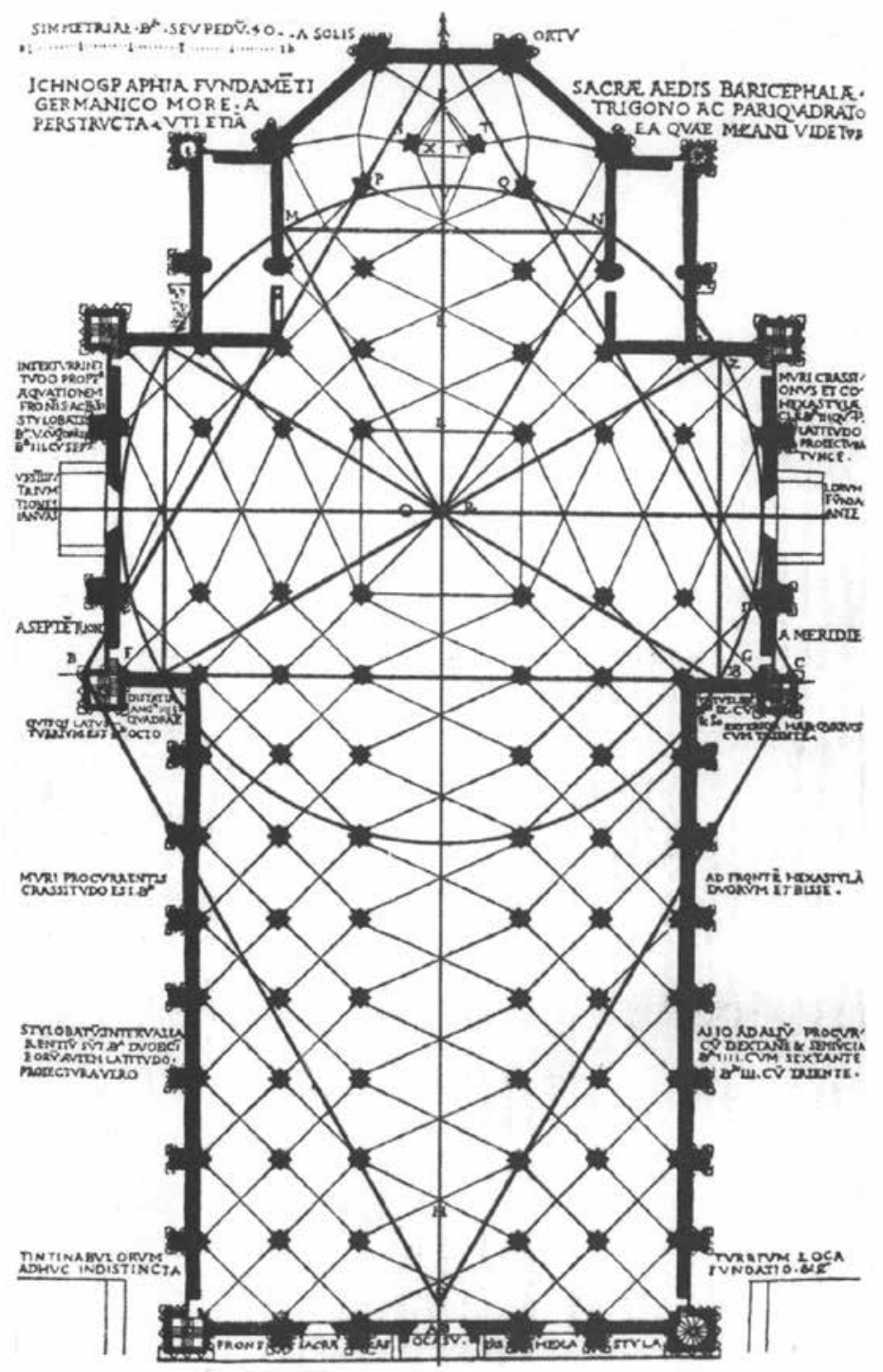

12. ábra. Cesare Cesariano rajza a milánói dómról, 1521 (forrás: Szakál 2007. 103) 
(1486-1490), Hans Schmuttermayer fiatorony- és wimpergakönyve (1487-1488), Lorenz Lacher fiához írt, 1516-os intelmei (Unterweysungen und Lehrungen für seinen Sohn Moritz) és Hans Hammer von Werde 15. század végi - 16. század eleji mühelykönyve minden bizonnyal a gótika delelőjén még féltve őrzött páholytitkokat tártak a nyilvánosság elé. A reneszánsz kibontakozása idején, a 15-16. század fordulóján a felbomlóban lévő gótikus mühelyekben felhalmozott építőtudást a feledés veszélye fenyegethette. Sódor szerint ezzel magyarázható a felsorolt könyvek megjelenése, amelyek azonban csak töredékét rögzítették a gótikus mesterek geometriai és tervezési módszereinek. ${ }^{176} \mathrm{~A}$ páholytitoktartás fellazulását támasztja alá, hogy Villard de Honnecourt 13. századi vázlatkönyvével ellentétben a német szerzők müveinek több kiadása és másolata maradt fenn. ${ }^{177} \mathrm{~A}$ tudást, amit egykor csak a mühely tagjainak szántak, a 15. század végére szélesebb közönség elé tárták. Hoppe László ezenkívül a reneszánszban teret hódító építészeti traktátusok hatását is felfedezni vélte a késő középkori mühelykönyvek megjelenésében. ${ }^{178}$ Azonban, míg Alberti, Filarete vagy Dürer az építészet elméletének megfogalmazására törekedtek, Roriczer, Schmuttermayer, Lacher és Hammer nem általános tervezési alapelveket fektettek le, hanem az általuk fontosnak tartott szerkesztési megoldásokat és arányosságokat gyüjtötték össze. ${ }^{179}$ Villard könyvéhez hasonlóan a német müvek sem utaltak a szerkesztések elméleti hátterére, csupán recepteket közöltek a tervezés segítésére. Ez tehát nagy valószínűséggel az egész gótikus építészet szakirodalmára jellemző volt, ugyanis Sódor szerint a 15. század végi müvekre a korábbi mühelykönyvek lehettek hatással, ahogyan maga Roriczer és Schmuttermayer is elödeikre, Konrad Roriczer regensburgi és nürnbergi dómépítő mesterre és a 14. századi „prágai junkerekre” hivatkoztak. ${ }^{180}$ Roriczer Geometria deutschának közvetett forrása lehetett a De inquisicione capacitatis figurarum ${ }^{181}$ címü, az 1440-es évek elött ismeretlen szerző által írt geometriai tárgyú kézirat, amely hasonló feladatokat tartalmazott, de Roriczer ezekből csak az egyszerü, körzős-vonalzós szerkesztéseket vette át, elméleti bizonyításokat nem. ${ }^{182}$ Sódor szerint ezenkívül a francia építészet és bizonyosan

${ }^{176}$ Sódor 1978a 21.

${ }^{177}$ Lorenz Lacher eredeti kézirata elveszett, de Jakob Feucht von Andernach másolatot készített róla 1593-1596-os mintakönyvében, amely tartalmazta Roriczer fiatoronykönyvét is. Roriczer fiatorony- és wimpergakönyvének nürnbergi, regensburgi és két würtzburgi (az eredeti 1486-os és egy későbbi, 1487-1488-as kiadás egybekötve) változata maradt fenn, ahogyan a Geometria deutsch is több kiadást ért meg (pl. a második kiadást P. Wagner 1498-ban Nürnbergben rendezte sajtó alá). Sódor 1982. 374-376.

${ }^{178}$ Hoppe 1994. 5.

${ }^{179}$ Sódor 1982. 376.

${ }^{180}$ Matthes Roriczer és Hans Schmuttermayer közös mestere Konrad Roriczer (Matthes apja) volt, akinek irányítása alatt mindketten (?) a nürnbergi Szent Lőrinc-templom szentélyén dolgoztak. Konrad apja, Wenzel Roriczer valószínüleg a csehországi Parler-mühelyben tanulta a geometria mesterségét, amikor 14111419-ig a prágai dóm építésén dolgozott. Erre utalhat, hogy mindkét fiatoronykönyv bevezetőjében a szerzők a szerkesztéseket nem saját találmányukként, hanem a prágai junkerekre hivatkozva mutatják be. Sódor 1978b 383. Schmuttermayer további forrásként említ bizonyos Rugert (talán a francia Roger) és Niclas von Straspurkot is. Sódor 1981. 194-195.

${ }^{181}$ Reinhard de Vurm 1440-es években összeállított gyüjteményes kötetében található.

${ }^{182}$ Sódor 1982. 377-378. 
a tervezéstechnika is nagy hatással volt a német gótika kialakulására és további fejlődésére, ezért a kései német szakirodalom tartalmi előképeit a Villardéhoz hasonló mühelykönyvek jelenthették. ${ }^{183}$

A német források közös vonása, hogy mindegyikben különösen fontos a quadratura szerepe. Roriczer és Schmuttermayer fiatorony-szerkesztése egyaránt a négyzet
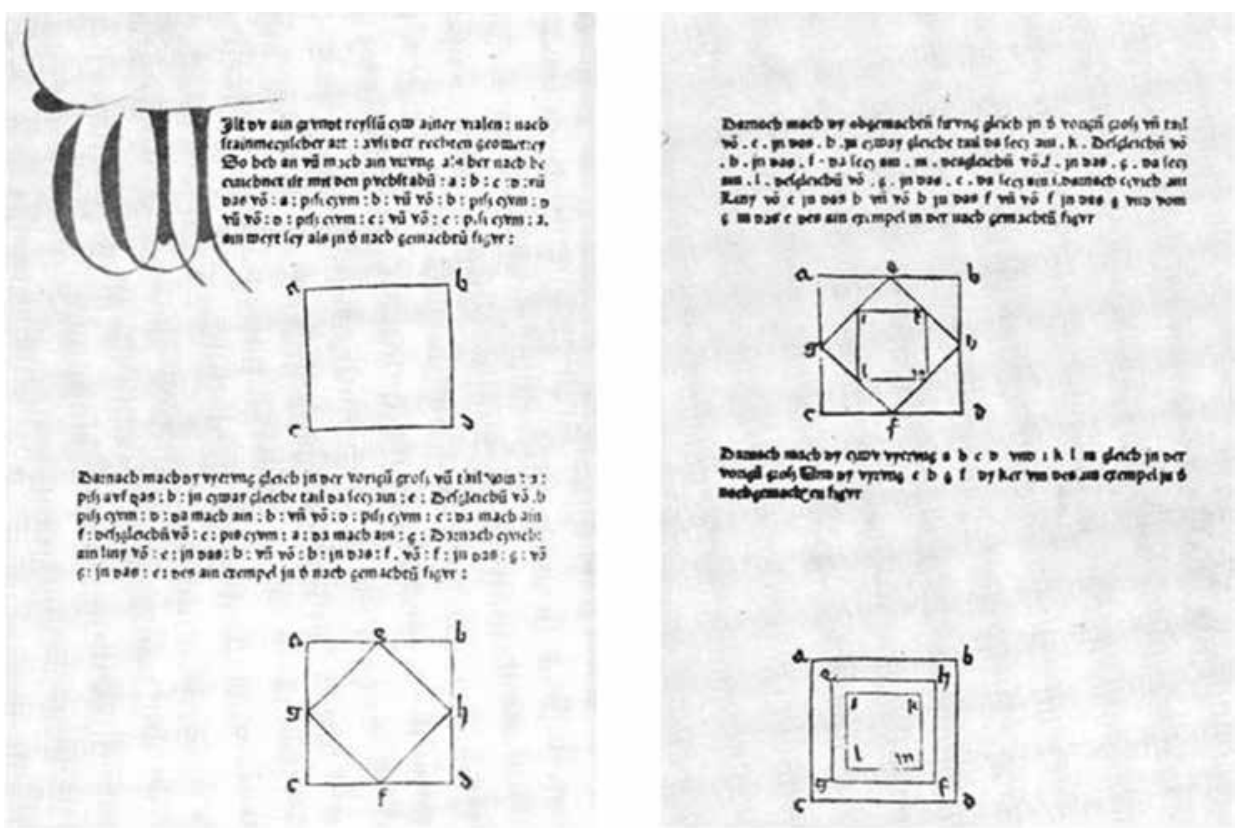

13. ábra. Matthes Roriczer fiatoronykönyvének részlete (forrás: Sódor 1978. 392, 394)
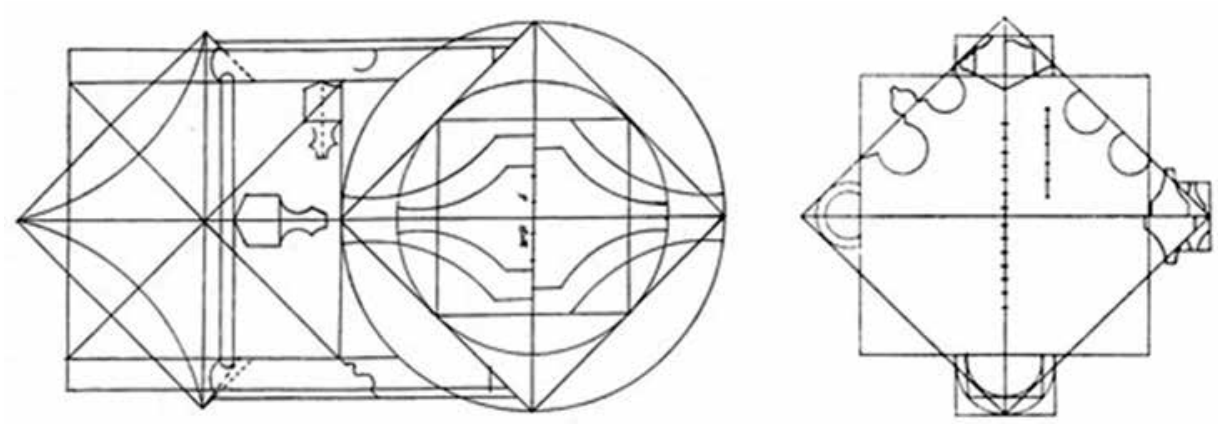

14. ábra. Lorenz Lacher profilszerkesztési mintái (forrás: Bork 2011. 8; Marosi 1997b 152)

${ }^{183}$ Ezt támasztja alá a fiatorony- és wimpergakönyvekben használt szakkifejezések francia eredete és a szerkesztési azonosságok is, pl. a négyzet felezése. Sódor 1981. 196. 
felezésének eljárására épült, amely során az oldalak felezőpontjával egy újabb, fele akkora négyzetet rajzolunk és ezt kellő számban megismételjük (13. ábra). Ugyanezzel a módszerrel találkozunk Villard de Honnecourt vázlatkönyvében, mind a kváderkő felezésében, mind pedig a jó arányú kolostorudvar készítésében, de még a laoni torony alaprajzában és a figurális alakokban is.

A quadratura alapszerkesztésének tekinthető eljárás tehát a gótika teljes korszakában és talán még korábban is jelen volt, nem hiába nevezte Villard a művészet igazi forrásának. ${ }^{184}$ A négyzet Lorenz Lacher könyvében is fontos szerepet játszik, ugyanis szerinte a templomfal vastagságára szerkesztett két elforgatott négyzetbe (nyolcszög) kell berajzolni az ablakmérmü profilját ${ }^{185}$ (14. ábra). Sztanekné Apai Gabriella kimutatta, hogy a quadratura minden esetben, a Lacher által közölt szabályok pedig többnyire jelen vannak a késő gótikus magyar kápolnák alaprajzában és részleteik profiljaiban. ${ }^{186}$ Roriczer szerkesztéseit bizonyítottan használták a regensburgi dóm tervezése során, amelynek mestere a szerző (Matthes Roriczer) apja, Konrad Roriczer volt. ${ }^{187}$ Mivel Wenzel Roriczer, Matthes nagyapja bizonyosan a fiatoronykönyvben említett „,prágai junkerek” tagja volt, a quadraturás szerkesztést nemcsak a francia és német mesterek, hanem a csehországi Parler-mühely eszköztárában is okkal feltételezhetjük.

Lorenz Lacher könyvéből a gótikus tervezés egyik legérdekesebb módszerét ismerhetjük meg, a toronyalaprajzok síkból történő kiemelését, amely a vízszintes és függőleges méretek közti kapcsolatot határozza meg. Lacher ugyanis a fiatoronykönyvekben is szereplö, a négyzet sorozatos felezésével előálló alaprajzi ábrához a függőleges vetületet a négyzeteknek megfelelő kockák egymásra szerkesztésével javasolta elkészíteni ${ }^{188}$ (15. ábra). Ez a módszer a bécsi Szent István-dóm már említett torony- és támpilléralaprajzának egykorú terve tükrében válik igazán érdekessé, ezek a tervek ugyanis az épületrészek különböző emeleti alaprajzait összerajzolva tartalmazzák $^{189}$ (16. ábra). Kérdéses, hogy ez az alaprajzi ábrázolástechnika az egész középkorra jellemző volt-e, vagy csak a bécsi mühely sajátosságai közé tartozott, illetve hogy Lacher „síkból kiemeléses” módszerét mennyire széles körben ismerték.

A késő gótikus német források is alátámasztják, hogy a középkorra a kóták nélküli tervezés, majd néhány helyszíni méret alapján történő újraszerkesztés, mint kitüzés, lehetett jellemző. Schmuttermayer fiatoronykönyvében így írt: „Ha egy fiatornyot és egy wimpergát akarsz rajzolni akkor elöször is csinálj egy négyzetet, mégpedig olyan nagyra, amilyenre akarod." ${ }^{190}$ A szerkesztések tehát bármilyen kiinduló méret-

\footnotetext{
${ }^{184}$ Sódor 1981. 196; Tompos-Zádor-Sódor 1975. 487-489.

${ }^{185}$ „Továbbá, vedd a szentély falvastagságát, legyen az kicsi vagy nagy, rajzolj egymáson keresztül két négyzetet, $\mathrm{s}$ ebben megtalálsz minden deszkát, amint ebben a könyvben lerajzolva látod egy nagy négyzetben, amit, hogy könnyebben megérthessed, lerajzoltam neked, ebbe a könyvbe az íás mellé." (Unterweisung) fordítás Marosi 1969. 219.

${ }^{186}$ Apai 1980. Függelék.

${ }^{187}$ Sódor 1978 b 386.

${ }^{188}$ Szakál 2007. 94; Sódor 1981. 197.

${ }^{189}$ Csemegi 1953. 19.

${ }^{190}$ Fordítás Sódor 1981. 202.
} 

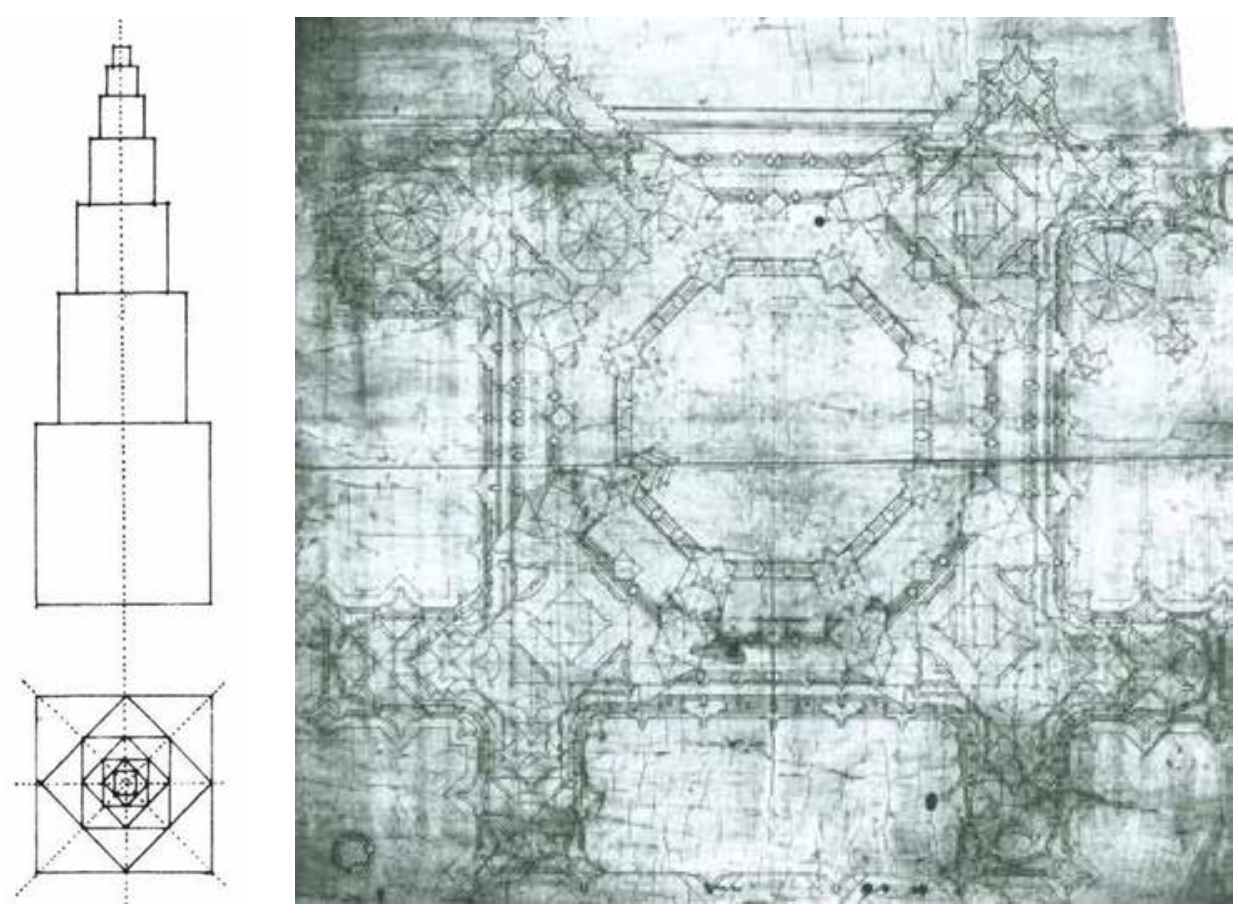

15. ábra. Lorenz Lacher eljárása az alaprajz síkból történő kiemelésére (forrás: Sódor 1981. 197)

16. ábra. A bécsi Szent István dóm északi tornyának egykorú alaprajza (forrás: Bork 2011. 259)

tel elvégezhetők voltak. Hoppe László ugyanerre a következtetésre jutott saját helyreállítási munkái során, amikor megállapította, hogy a csarodai és vámosatyai templom (13. század vége, 14. század eleje) alaprajzi szerkesztése minden lényeges ponton megegyezik, a rendszer alapját jelentő méret azonban eltérö. ${ }^{191}$ Hoppe szerint a két templomot valószínűleg azonos műhely építette, amely a már bevált tervezési sémát két épületen is felhasználta. ${ }^{192}$ Az eltérő alapméretek oka valószínűleg a helyi adottságokra és igényekre vezethető vissza.

Ahogyan Villard vázlatkönyvéből, úgy a kései német irodalomból is láthatjuk, hogy milyen tervezési és építészeti kérdések foglalkoztatták az adott kor mestereit, illetve hogy melyek voltak az igazán problémás épületrészek. A fiatornyon és a wimpergán kívül Roriczer leírta a derékszög, az ötszög és a hétszög szerkesztését, továbbá egy kör kerületének grafikus meghatározását. Ilyen és ezekhez hasonló eljárások lehettek a tervezés alapfeladatai, de az is elképzelhető, hogy Roriczer éppen a nehe-

\footnotetext{
${ }^{191}$ Hoppe 1993. 368-369. A hajók szélességének és hosszának, a szentélyek és a diadalívek és a szentély falvastagságának szerkesztése megegyezik.

${ }^{192}$ Hoppe 1994. 8.
} 
zebb, és ennél fogva ritkábban választott megoldásokat gyüjtötte össze. Az ötszög esetében felmerül, ahogyan a Sedlmayr által vizsgált soproni mérmüves ablakok kapcsán már említettük, hogy alkalmazásával a tervező ritka geometriai tudását akarta bemutatni. ${ }^{193}$ Lorenz Lacher Unterweisungja kivételesen sok arányossági elöírást tartalmaz, amelyeket a szerző valószínűleg saját építészeti praxisa során tanult meg vagy tapasztalt ki, föleg a szentélyek tervezésével kapcsolatban ${ }^{194}$ - ez a probléma tehát Villardhoz hasonlóan a 15-16. századi építészeket is módfelett érdekelhette. Sztanekné Apai Gabriella több késő gótikus kápolna terveiben a szentélyszerkesztés Lacher által lefektetett elveit kereste, amelyeket nem tudott minden esetben maradéktalanul kimutatni. ${ }^{195}$ Ez nem jelenti azt, hogy Lacher tervezési elvei, vagy azokhoz hasonlók ne lettek volna használatosak, csupán arra világít rá, hogy a középkori szakirodalom nem kötelező érvényü szabályokat rögzített, hanem lehetőségeket, recepteket, amelyeket a különböző generációk saját tapasztalataik alapján módosítottak, kiegészítettek. Csemegi József sajátos fejlődési vonalat határozott meg a Hans Stethaimerhez és köréhez köthető szentélykörüljárós csarnoktemplomok elemzése alapján. ${ }^{196}$ Eszerint a mester hatszöges alaprajzi szerkesztésmódját a gmündi Heinrich Parlertől vehette, ${ }^{197}$ amit később a landshuti, dingolfingi és wasserburgi templomoknál (15. század második fele) módosítva, $90^{\circ}$-kal elforgatva alkalmazott. Ezzel a szerkesztéssel a fö- és mellékhajók szélessége függetlenedett egymástól, amit Csemegi Stethaimer tervezői egyéniségének a geometriai szerkesztések kötöttségei alóli felszabadulásaként értelmezett a 15. század végén. ${ }^{198}$

A szentélyekhez hasonló összetett tervezési feladatot jelenthettek a térlefedő szerkezetek, amelyek a gótika utolsó szakaszában megjelenő háló- és csillagboltozatok-

\footnotetext{
${ }^{193}$ Sedlmayr 1992. 22.

${ }^{194}$ „Ezért először azzal akarom kezdeni, és meg akarom mutatni, hogyan tudsz a sokféle épületnél kezdettől végig helyes mértéket tartani, ismerve alapjukat és mértéküket, és más épületekröl is mintákat akarok neked mutatni. Továbbá a kőfaragó munkák szerkesztéséről, hogyan kell azt csinálni a legművészibb falazókővel, nagy és kis épületeknél. (...) És ezért, ha tudni akarod, hogyan vagy képes nyerni valamennyi deszkát, tudnod kell a falak magasságát és szélességét, aszerint, hogy az épület kicsi vagy nagy, a kő kemény vagy lágy, hogy mihez tartsd magadat, és hogy a pillért kőrácsokkal törd át, minden szükséges dolgot tudni kell a vastagságról és szélességről és a párkány formájáról is. (...) Továbbá, ha egy szentély belülről 20 láb széles, másfélszer olyan magasnak kell lennie, mint amilyen széles, ez a helyes magassága. (...) És akár szűk, akár széles a kórus, a fôpárkánynak olyan magasan kell lennie, amilyen távolságra a pillérek egymástól állnak, a lábazati párkánytól a főpárkányig négyzetet alkotva. Továbbá, a lábazati párkánynak olyan magasan kell lennie, amilyen vastag a pillér, és ahol a talaj szintje egyenetlen, ott a lábazati párkány is lefelé halad. (...) Továbbá, ha egy szentély belül 20 láb széles, és a kő jó, csináld a falakat két láb vastagra, ha azonban a szentély nemes faragott kőmunkából áll, végy el belőle 3 hüvelyket, ha pedig gyengébb a kő, a falak és a pillérek vastagságához adj hozzá 3 hüvelyket." (Unterweisung) fordítás Marosi 1969. 217-219.

${ }^{195}$ Apai 1980.

${ }^{196}$ Csemegi 1935, 1937.

${ }^{197}$ Csemegi szerint a gmündi Heiliggeistkirche (Parler Henrik) és a staubingi Szent Jakab-templom (Hans Stethaimer) fö- és mellékhajóinak szélességét azonos módon szabályos hatszög segítségével tủzték ki. Csemegi 1935. 9-10. Parler Henrik már a milánói dómépítkezés vitája kapcsán is a háromszöget javasolta a hajó magasságának meghatározására. Marosi 1969. 210.

${ }^{198}$ Csemegi 1935. 11.
} 

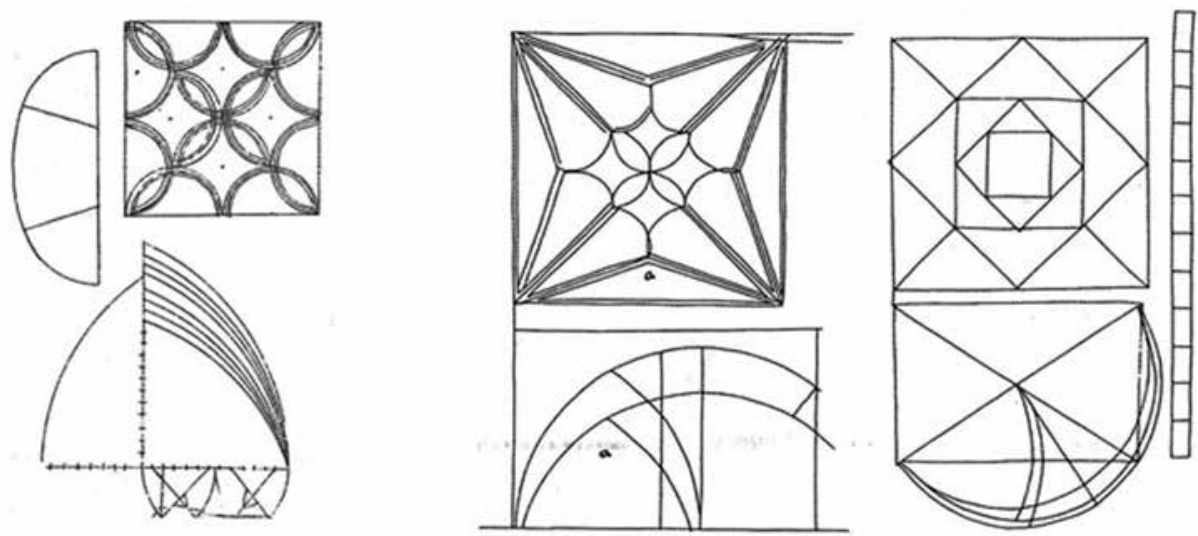

17. ábra. Boltozatszerkesztési részletek a Bécsi mintakönyvből és a Frankfurti mintakönyvből (forrás: Marosi 2008. 10, 12)

kal egyre bonyolultabbá váltak. A térlefedések tervezési nehézségéről tanúskodik az úgynevezett Bécsi mintakönyv ${ }^{199}$ és Frankfurti mintakönyv ${ }^{200}$ (15. század vége), amelyeknek több rajza szentélyek fölé szerkesztett hálóboltozatokat ábrázol (17. ábra). Horváth Henrik leírta, hogy mesterremekként két magyar céhszabályzat, a brassói (1570) és a kassai (1573) egy keresztboltozat helyes szerkesztését követelte meg, amelyeknél fontos szerepe volt a szemmértéknek, mert ezeket a szokásos müszerek nélkül kellett elkészíteni. ${ }^{201} \mathrm{Ez}$ arra enged következtetni, hogy a gótikus mühelyekben egyes részleteket, például profilokat tervezhettek akár szabad kézzel is. A boltozatok geometriájának megértéséhez, bemutatásához nemcsak rajzokat, hanem famodelleket is készítettek. Erről tanúskodnak a mesterremekek, ${ }^{202}$ de elképzel-

${ }^{199}$ Szakál 2007. 97; Szőke 2005. 885. Forrása Hans Koepf: Die gotischen Plenrisse der wiener Sammlungen. Bécs 1969. „Ha valaki kórust akar csinálni, és helyes magasságát meg akarja adni, tudnia kell, hogy az első fajtánál a kórus szélességének másfélszerese kell legyen a tetejéig, a másik fajta kórusnak háromszor olyan magasnak kell lennie a tetejéig, mint amekkora a szélessége. És ha a kórusoknak mellékhajóik lennének, amilyen széles egy mellékhajó, és amilyen széles mindegyik kórus, háromszor olyan hosszúnak kell lennie. És a pilléreknek, amelyek kívülröl a kórushoz tartoznak, kétszer olyan hosszúaknak kell lenniük, mint amilyen szélesek. (...) Aki helyesen akar megcsinálni egy müvet, annak tudnia kell, hogy a bordáknak és a hevedereknek egyenlő magasan kell lenniük a felső kőrétegen, és a hevedereknek másfél lábnyival alacsonyabbaknak kell lenniük, mint a zárókő. (...) Aki helyes boltozatot akar csinálni, annak a körzőt kinyitva, azt mindenekelőtt ki kell szerkesztenie, s tudnia kell, hogy a hevedereknek és a föíveknek egy körzőnyílással kell rendelkezniük, és minden egyes darabnak kétszer olyan hosszúnak kell lennie, mint amilyen széles.” Fordítás Marosi $1997 \mathrm{~b} 229$.

${ }^{200}$ Marosi 2008. 12-13.

${ }^{201}$ Horváth 1935. 49.

${ }^{202}$ Sódor 1979. 5. Az említett mestermunkák 1659-ből és 1755-ből (Nürnberg) valók, amelyek egy a középkorból megmaradt hagyomány példáiként értelmezhetők a páholyok müködésében. Forrásaik: Werner Müller: Das Sterngewölbe des Lorenzer Hallenchores: seine Stellung innerhalb der spätgotischen Gewölbekonstruktionen. In: 500 Jahre Hallenchor St. Lorenz zu Nürnberg 1477-1977. Nürnberg 1977. 171-196; Friedrich Hoffstadt: Gotisches ABC Buch: das ist: Lehrbuch der Grundregeln des gotischen Styls, und insbesondere der gotischen Architektur. Frankfurt 1845. 14/B tábla. 
hető, hogy a későbbi munkák során is gyakran terveztek modellek segítségével. Sódor Alajos 16-18. századi leírások alapján megállapítja, hogy a bordás boltozatok tervezésénél az úgynevezett vezérgörbe szerkesztést alkalmazták, amelynek lényege, hogy bármilyen bonyolult rajzolatú boltozat föbordáit (de lehetőleg mindet) azonos körívvel rajzolták meg. Eszerint a háló- és csillagboltozatok tervezése alapvetően eltér egyes keresztboltozatokétól. ${ }^{203} \mathrm{~A}$ vezérgörbés módszernél először a bordarendszer geometriája áll elö, a boltozat méretei ebböl következnek. ${ }^{204} \mathrm{~A}$ hálóboltozatok esetében a tervezés menete megegyezik a kivitelezésével: először a borda készül el, majd a mezö, ezért csak a vezérgörbe sugarát kellett pontosan megszerkeszteni ahhoz, hogy az elemek faraghatók legyenek. A tervezési folyamat azonban nem egyszerüsödött le, hiszen az alaprajzi vetület és a bordaváz kompozíciója komoly átgondolást igényelt. Szőke Balázs a Szeged-alsóvárosi templom hajóboltozatának modellezése kapcsán arra, a szakirodalomban többször feltett kérdésre kereste a választ, hogy a térlefedés valódi bordás boltozatként vagy inkább álbordás fiókos dongaként értelmezhető. ${ }^{205} \mathrm{~A}$ Sódor által ismertetett vezérgörbe-szerkesztés értelmében a késő gótikus csillag- és hálóboltozatok bordacsomópontjai (vagy akár maguk a bordák is) donga-, illetve gömbfelületre illeszkednek, ${ }^{206}$ ahogyan a Szeged-alsóvárosi templomban is.

A vezérgörbés módszer mellett egyéb szerkesztési eljárások is kimutathatók a gótikus emlékek geometriájában. Az érintőkörös szerkesztésre nemcsak Sedlmayr János és Czagány István hívta fel a figyelmet, hanem Szakál Ernő is, aki saját rekonstrukciós munkáit is ezzel a módszerrel végezte ${ }^{207}$ (18. ábra). Czagány szerint a budavári anyagban már a 13. században, a Mátyás-templom főhomlokzati rózsaablakán kimutatható az érintőkörös módszer alkalmazása, de leginkább a 15. században terjedt el.

Szintén ő ismertette pontok és vonalak körzős forgatással történő kijelölését, ${ }^{208}$ de hasonló eljárásokkal már Möller is kísérletezett ${ }^{209}$ (19. ábra). A szerkesztési módszerek halmozott, bonyolult alkalmazása Czagány szerint a késő gótika dekadens korszakát jellemezte. ${ }^{210}$ Mások éppen a geometria racionalizálására hívták fel a figyelmet, mint Csemegi József, aki szerint a késő gótikus boltozatok vezérgörbés szer-

\footnotetext{
${ }^{203}$ Egyeneszáródású bordás keresztboltozatok esetében. A késő gótikus boltozatok szerkezetéről bővebben lásd: Császár 1983.

${ }^{204}$ Sódor 1979. 1-2.

${ }^{205}$ A hajóboltozat meghatározását az építés idejének (16. század elején vagy a török hódoltság után újjáépítve) bizonytalansága is megnehezíti. Szőke szerint elképzelhető, hogy a térlefedés a gótikus építészet példája és valódi bordás szerkezetű. Szőke 2005. 890. A kérdés további lehetséges megközelítése a statikai erőjáték vizsgálata is lehet.

${ }^{206}$ Sódor 1979. 4-5. A gömbfelületre illeszkedő bordaváz példájának forrása: G. Ungewitter: Lehrbuch der gotischen Konstruktionen 1. Tauschnitz, Leibzig 1901. 19. tábla.

${ }^{207}$ Sedlmayr 1992. 20-21; Czagány 1985. 405; Szakál 2007. 117-119.

${ }^{208}$ Czagány 1985. 414. A $60^{\circ}$-os szerkesztéssel párosított körzős forgatást Czagány az Országház utca 18. sz. házban lévő cseh-sziléziai eredetü profil geometriájában mutatta ki.

${ }^{209}$ Például BME Éptört Rajztár 102443; 102654; 102689.

${ }^{210}$ Czagány 1978. 173.
} 


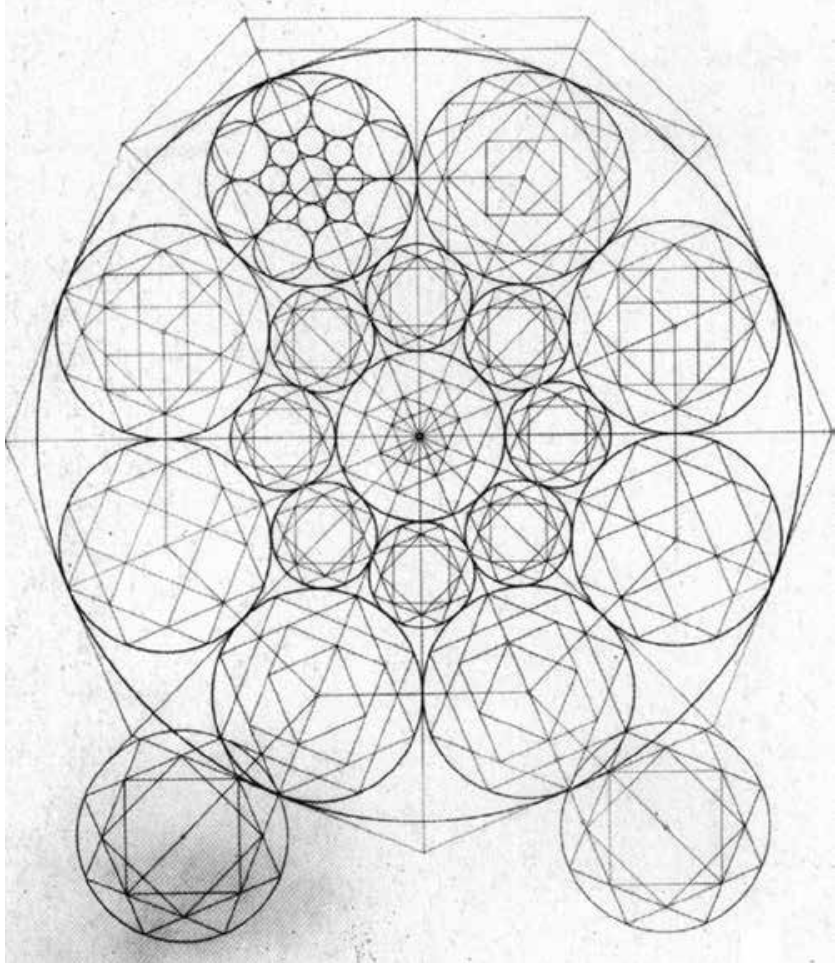

18. ábra. Szakál Ernő terve a visegrádi Anjou-kori kútház rekonstrukciójára, az érintőkörös szerkesztés vázlata, 1964 (forrás: Szakál 2007. 118)
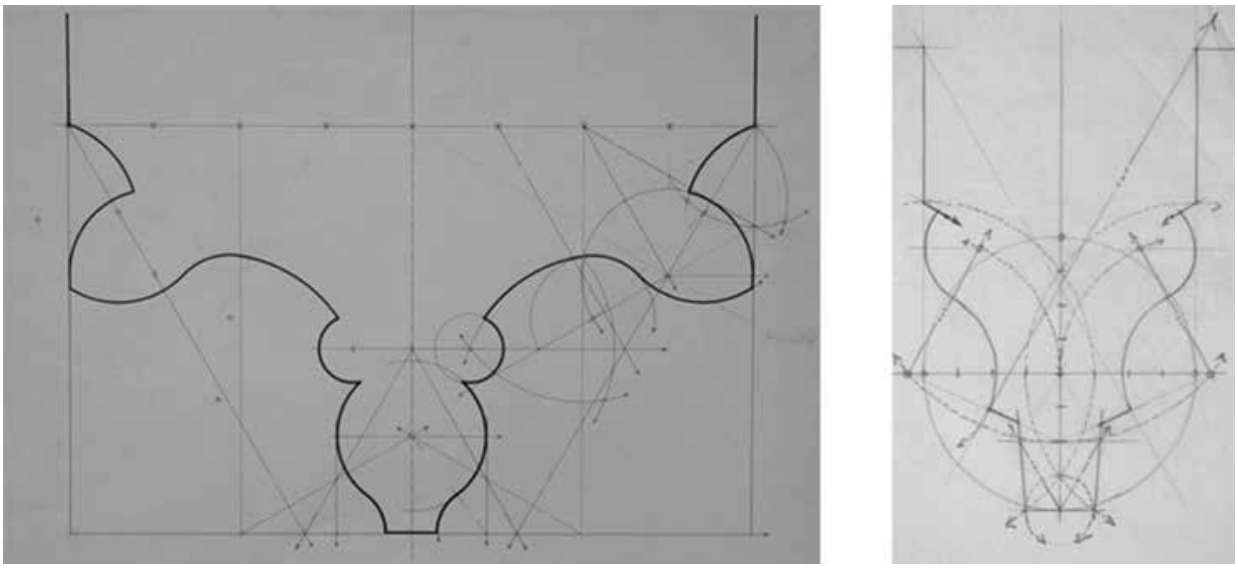

19. ábra. Möller István profilszerkesztései, 1916 (Gyulafehérvár, székesegyház) (forrás: BME Éptört Rajztár 102654, 102689) 
kesztése a bordák tipizálását és előregyártását tette lehetővé. ${ }^{211}$ Hasonlóan vélekedett Sztanekné Apai Gabriella is, aki szerint a késő gótikus térlefedések és bordaprofilok készítését tömegtermelésként képzelhetjük el, mivel ezek a mintakönyvek ökölszabályait követték. ${ }^{212}$ Sódor a 16. századi boltozatokat a reneszánsz idejében még létező utógótikához kötötte, amelyek szerkezeti értelemben már nem képviseltek valódi progresszivitást az érett korszakhoz képest. Ezek oktató szakirodalmaként értelmezhetők a kései mintakönyvek, amelyek leegyszerüsített geometriai szabályai az egykor virágzó tervező-építő kultúrának csupán kivonatai voltak. ${ }^{213}$

A gótikus építészet geometriai elemzése során sejthető, hogy a teljes épület és nagyobb vagy kisebb részek között összefüggés lehet, lényegük, tervezési elvük azonos, a szakirodalom ennek ellenére ritkán említi a részek és az egész viszonyát. ${ }^{214}$ Az összhang konkrét bizonyítékát a korabeli források között csak Lachernél találhatjuk meg, aki a szentély falának vastagságát a szélességből eredeztette (annak 1/10-e), az ablakok mérmüprofiljait pedig a falvastagságba rajzolt nyolcszög segítségével rajzolta meg. ${ }^{215}$ Gerevich Tibor szerint a részek és az egész épület arányai azért azonosak, mert azonos szerkesztési elv alapján alkották őket. Míg a teljes alaprajz és metszet tervezéséhez inkább statikai tudás kellett, a profilok megrajzolásához inkább geometriai ismeretek. ${ }^{216}$ Sódor Alajos a skolasztikus filozófia hármas elvrendszerét - teljességre törekvés; összhang az egyes részek és az egész között; világos megfogalmazás - Erwin Panofsky elmélete alapján a gótikus építészetre is alkalmazta. ${ }^{217}$

A rész és egész összefüggésének feltárását az épület vizsgálatakor sokszor megnehezítheti a terv és a megvalósulás közötti viszony, amelyet rész és egész esetében más folyamatok alakíthatnak. Nyilvánvaló, hogy geometriai-aritmetikai összefüggések az épület alaprajzi elrendezését, magassági méreteit, a tér dimenzióját is meghatározták, ezek azonban gyakran változtak a hosszú ideig zajló kivitelezés vagy a későbbi átépítések során, és nem lehetünk bizonyosak abban, hogy mennyire hü leképezései a terv által képviselt ideának. A részletek esetében azonban a tervezés és kivitelezés sokkal inkább szerves folyamat, és jóval kevésbé kell számolnunk olyan tényezőkkel - helyszíni adottságok, talajviszonyok, statikai megfontolások, kivitelezési költségek -, melyek a tiszta geometria szempontjait felülírhatják.

Ahogyan a korai középkori szerkesztőmódszerek előzménye és alapja az ókori hagyományokban keresendő, nem hanyagolhatjuk el a gótikus gyakorlat továbbélését sem a későbbi korokban. A reneszánsz szellemiség ugyan tudatosan új arányos-

\footnotetext{
${ }^{211}$ Csemegi 1953. 34-35. A késő gótikus boltozatok tipizálását és előregyártását Csemegi a szocialistarealista acél és vasbeton építészettel, a típustervekkel és a szabványos épületelemekkel állította párhuzamba. Szintén az előregyártást említette Marosi 2008. 10, 12. A késő gótikus hálóboltozatok és kortárs szerkezetek további figyelemre méltó párhuzama: Masznyik 2011. 272-277.

${ }^{212}$ Apai 1980. Függelék 11.

${ }^{213}$ Sódor 1978a 21.

${ }^{214}$ Czagány 1978. 150-151.

${ }^{215}$ Marosi 1969. 218-219.

${ }^{216}$ Gerevich 1910. 54, 57.

${ }^{217}$ Sódor 1984. 78; Sódor 1978a 17. Erwin Panofsky: Gothic Architecture and Scholasticism. Cleveland 1961. alapján.
} 
sági rendszerek felé fordult, a középkor geometriai eljárásai azonban részben folytonosan, részben újjáledve fellelhetők. Ilyen jelenséggel már a barokk építészetben is találkozunk, ${ }^{218}$ virágkorát pedig a már bővebben tárgyalt 19. századi historizáló törekvésekben élte. Napjainkban a müemlékvédelmi helyreállítások kulcsfontosságú feladata az emlékek eredeti szerkesztőmódszerének rekonstruálása a történeti hüség érdekében, amely nemcsak a középkori, hanem minden történeti épület esetében elengedhetetlen.

\section{ZÁRSZÓ}

E tudománytörténeti áttekintés legfontosabb tanulságaként a vizsgálat lehetséges további irányait érdemes kijelölni. A téma felvetésének aktualitását elsősorban az adja, hogy napjainkban a müemléki épületkutatás és épületrégészet a korszerü felmérési technikák újabb és újabb módszereit alkalmazza, és az eljárások egyre szélesebb körben válnak hozzáférhetővé. A fotogrammetria, a lézerszkenner, és más digitális technikán alapuló módszerek nagyban meggyorsíthatják a helyszíni adatgyüjtés folyamatát és növelik a mérés pontosságát, a segítségükkel összegyüjthető hatalmas és vitathatatlan értékủ adathalmaz kiértékelésében pedig ugyancsak a számítógépet kell segítségül hívnunk. Vitathatatlan, hogy a digitális méréstechnika mára a müemléki kutatás fontos segédtudományává vált. Fontos hangsúlyozni azonban, hogy az építészettörténeti szempontból releváns jelenségek felismerése, az emlék keletkezésével kapcsolatos geometriai elmélet megalkotása továbbra is a kor tervezési elveivel tisztában lévő kutató feladata. Elödeink eredményeinek birtokában tudunk megfelelő kérdéseket feltenni, és ugyancsak a korábbi kutatások kritikai elemzése segít bennünket a tévutak elkerülésében. Az adatgyüjtés és adatelemzés forradalma azonban minden eddiginél nagyobb lehetőséget nyújt az elméletek összevetésére, igazolására vagy cáfolatára. Az erre irányuló összehasonlítás alapja mindeddig - néhány kivételesen szerencsés esetet leszámítva, mikor a kutatónak lehetősége volt valamennyi érdeklődési körébe tartozó objektum alapos helyszíni vizsgálatára - publikált felmérések falhasználása volt. Itt azonban az elemző egy szükségképpen idealizált formával volt kénytelen dolgozni, ahol a mintavétel ${ }^{219}$, a mérés, a felszerkesztés, sőt, a nyomdai feldolgozás során is pontatlanságok kerülhettek a rendszerbe. Megfelelő körültekintéssel végzett korszerủ felmérés eredményeképpen viszont - a geometria szempontjából legalábbis - az objektum tulajdonképpeni másolata áll elő, melyen a kutató a saját szempontjai szerint vizsgálhatja a méreteket.

\footnotetext{
${ }^{218}$ Példaként említhető Eupen (1721-1724), Bückeburg (1613-1615) és Hagen (18. század) csarnoktemploma, melyeknek alaprajzi szerkesztésében Hans Stethaimer gmündi arányozási rendszere mutatható ki. Csemegi 1937. 341-342.

${ }^{219}$ Egy profil felmérése esetében gyakran feltételezhető, hogy a felmérő csak egy, többé-kevésbé önkényesen kiválasztott szelvényben végez mérést, ezzel figyelmen kívül hagyva azt a lehetőséget, hogy a kivitelezés méretpontatlanságából eredően a profil az elem hosszán változhat.
} 


\section{IRODALOM- ÉS RÖVIDÍTÉSJEGYZÉK}

Apai 1980

Bork 2011

Czagány 1978

Czagány 1985

Császár 1983

Császár 2001

Csemegi 1935

Csemegi 1936

Csemegi 1937

Csemegi 1941

Csemegi 1953

Csemegi 1960

Entz 1973

Finánczy 1926

Frőde 1900

Gerevich 1910

Gerevich 1971

Gergelyffy 1958

Gevers-Molnár 1972

Guzsik 1975

Guzsik 1990

Guzsik 1994a
Sztanekné Apai Gabriella: Késő gótikus kápolnák Magyarországon. Doktori disszertáció. BME Építészettörténeti és Elméleti Intézet, Budapest 1980.

Robert Bork: The Geomerty of Creation. Ashgate, Farnham 2011.

Czagány István: A budavári gótika tervezéstechnikai rendszerei. Ülőfülkeszerkesztések. Épités- Épitészettudomány 10 (1978) 1-2. 149188.

Czagány István: A budavári gótika tervezéstechnikai módszerei és összefüggései. Építés- Épitészettudomány 17 (1985) 3-4. 397-452.

Császár László: Megfigyelések a késő gótikus boltozatszerkesztés egyes eljárásairól. Épités- Építészettudomány 15 (1983) 1-4. 41-53.

Császár László: Középkori szerkesztési módszerek és Szakál Ernő művészete. Müemlékvédelem 45 (2001) 1. 27-32.

Ifj. Csemegi József: Fejezet az egri várszékesegyház építésének történetéből. Kny. A Magyar Mérnök és Épitész Egylet Közlönye 69 (1935) 11-12., Stádium Sajtóvállalat 1935.

Ifj. Csemegi József: Tervezés-technikai kérdések a középkori építészetben. Kny. A Magyar Mérnök és Épitész Egylet Közlönye 70 (1936) 7-12., Stádium Sajtóvállalat 1936.

Ifj. Csemegi József: Szentélykörüljárós csarnoktemplomok a középkorban. A Magyar Mérnök és Épitész Egylet Közlönye 71 (1937) 49-50. 337-345.

Ifj. Csemegi József: Jegyzetek az egri székesegyház építéstörténetéhez. A Magyar Mérnök és Építész Egylet Közlönye 75 (1941) 92-94.

Csemegi József: A középkori építészet szerkesztési módszerei. Magyar Müvészettörténeti Munkaközösség Évkönyve 1953.

Csemegi József: Közép-Európa románkori centrális templomainak építészettörténeti kérdései. Építés- és Közlekedéstudományi Közlemények 4 (1960) 3. 323-348.

Entz Géza: A gótika müvészete. Corvina, Budapest 1973.

Finánczy Ernő: A középkori nevelés története. Királyi Magyar Egyetemi nyomda, Budapest 1926.

Frőde Vilmos: Felső-Magyarország középkori épületeinek kőfaragó jelei. A Magyar Mérnök és Épitész Egylet Közlönye 34 (1900) 18. 421-443.

Gerevich Tibor: Az építési munka szervezete a középkorban. Budapesti Épitömesterek Ipartestületének Évkönyve 6 (1910) 33-89.

Gerevich László: Villard de Honnecourt Magyarországon. Müvészettörténeti Értesítö 20 (1971) 2. 81-105.

Gergelyffy András: A műemlékvédelem múltjából (Henszlmann Imre és a bélapátfalvi templom). Müemlékvédelem 2 (1958) 205-210.

Gevers-Molnár Vera: A középkori Magyarország rotundái. Akadémiai Kiadó, Budapest 1972.

Guzsik Tamás: Tájolási rendellenességek a középkori templomépítészetben. Épités- Épitészettudomány 7 (1975) 1-2. 91-104.

Guzsik Tamás: Szimbólumok a középkori örmény építészetben. ÉpitésÉpítészettudomány 21 (1990) 1-4. 129-163.

Guzsik Tamás: Középkori épitészettörténeti ábraanyag I. Róma és a keresztény kelet szakrális épitészete. BME Építészettörténeti és Elméleti Intézet, Budapest 1994. 
Guzsik 1994b

Guzsik 1994c

Hajnóczi 1956

Hajnóczi 1996

Henszlmann 1860

Henszlmann 1863

Henszlmann 1864

Henszlmann 1866a

Henszlmann 1866b

Henszlmann 1870

Henszlmann 1873

Henszlmann 1876

Henszlmann 1878

Henszlmann 1880

Hoppe 1993

Hoppe 1994

Hoppe 1995

Horváth 1935

Levárdy 1969

Marosi 1969

Marosi 1997a

Marosi 1997b

Marosi 2008

Masznyik 2011

Myskovszky 1878
Guzsik Tamás: Középkori épitészettörténeti ábraanyag II. A népvándorláskor és a romanika szakrális épitészete. BME Építészettörténeti és Elméleti Intézet, Budapest 1994.

Guzsik Tamás: Középkori épitészettörténeti ábraanyag III. A gótika szakrális épitészete. BME Építészettörténeti és Elméleti Intézet, Budapest 1994.

Hajnóczi Gyula: Müemlékfelmérés. Építőipari Műszaki Egyetem Tudományos Közleményei, Budapest 1956.

Hajnóczi Gyula: A középkor építészetelmélete. Épités- Épitészettudomány 26 (1996) 3-4. 238-264.

Henszlmann Imre: Méthodes des proportions dans l'architecture égyptienne, dorique et du Moyen Âge. Párizs 1860.

Henszlmann Imre: A kis-bényi román izlésủ egyház. Archeológiai Közlemények 3 (1863) 1. 3-34.

Henszlmann Imre: A székes-fehérvári ásatások eredménye. Heckenast, Pest 1864.

Henszlmann Imre: A bélhárom-kuti, másképp apátfalvi egyháznak építészeti arányai. Archeológiai Közlemények 6 (1866) 1. 61-82.

Henszlmann Imre: Mürégészeti kalauz I-II. Pest 1866.

Henszlmann Imre: Pécsnek középkori régiségei I. Athenaeum, Budapest 1870 .

Henszlmann Imre: Die Grabungen des Erzbischofs von Kalocsa Dr. Ludwig Haynald. Athenaeum, Budapest 1873.

Henszlmann Imre: Magyarország ó-keresztény, román és átmenet stylü mü-emlékeinek rövid ismertetése. Magyar Királyi Egyetemi Könyvnyomda, Budapest 1876.

Henszlmann Imre: Löcsének régiségei. Magyar Tudományos Akadémia Könyvkiadó Hivatala, Budapest 1878.

Henszlmann Imre: Magyarország csúcs-íves stylü müemlékei. Magyar Királyi Egyetemi Könyvnyomda, Budapest 1880.

Hoppe László: A történeti építészet méretmeghatározó módszerei. ÉpitésÉpitészettudomány 23 (1993) 3-4. 351-388.

Hoppe László: Késő gótikus méretrend Hans Hammer vázlatkönyvéből. Müemlékvédelmi Szemle (1994) 2. 5-20.

Hoppe László: Az ötszög szerkesztése a középkorban: Hans Hammer ötszögszerkesztése. Épités- Épitészettudomány 25 (1995) 1-2. 139-171.

Horváth Henrik: Budai kőfaragók és köfaragójelek. Székesfőv. háziny., Budapest 1935.

Levárdy Ferenc: Henszlmann alkotó egyénisége. Müvészettörténeti Értesitő 18 (1969) 3. 193-200.

Marosi Ernő: A középkori müvészet világa. Gondolat, Budapest 1969.

Marosi Ernö: A középkor müvészete II. 1250-1500. Corvina, Budapest 1997.

Marosi Ernő: A középkori müvészet történetének olvasókönyve. Balassi, Budapest 1997.

Marosi Ernő: A gótika Magyarországon. Corvina, Budapest 2008.

Masznyik Csaba: Ne remélje, hogy megszabadul Euklidésztöl. Épités Épitészettudomány 39 (2011) 3-4. 257-278.

Myskovszky Viktor: Az úgynevezett ,arany metszet” aesthetikai törvényének alkalmazása a csúcsíves stílben. Archeológiai Közlemények 12 (1878) 1. 101-111. 
Sapin 1996

Sedlmayr 1992

Sódor 1978b

Sódor 1979

Sódor 1981

Sódor 1982

Strommer 2008

Szakál 1977

Szakál 2007

Szekér 1992

Szekér 2014

Szőke 2005

Szőke 2009
Sódor 1974

Sódor 1978a

Christian Sapin: L'origin des rotondes mariales des $\mathrm{IX}^{\mathrm{e}}-\mathrm{XI}^{\mathrm{e}}$ siècle et le cas de Saint-Germain d'Auxerre. In: Dominique Iogna-Prat et al: Marie. Le culte de la Vierge dans la Socété médiévale. Beauchesne, Párizs 1996. 295-312.

Sedlmayr János: Két különleges mérmủves ablak a soproni Szent Mihálytemplomon. Müemlékvédelem 36 (1992) 1. 17-22.

Sódor Alajos: Gótikus katedrális épitészet Európában. Kandidátusi értekezés, Műszaki Egyetem Építésztetörténeti és Elméleti Intézet Mủemléki Osztály, Budapest 1974.

Sódor Alajos: Az épitészeti tervezés alaptendenciái a középkorban. Egyetemi jegyzet. Müszaki Egyetem Építésztetörténeti és Elméleti Intézet Múemléki Osztály, Budapest 1978.

Sódor Alajos: Matthes Roriczer 1496-ban megjelent fiatorony könyve. Épités- Épitészettudomány 10 (1978) 3-4. 381-421.

Sódor Alajos: Kései gótikus boltozatok szerkesztése. Egyetemi jegyzet. Müszaki Egyetem Építésztetörténeti és Elméleti Intézet Mủemléki Osztály, Budapest 1979.

Sódor Alajos: Hans Schmuttermayer kései középkori fiatorony könyve. Épités- Épitészettudomány 13 (1981) 1-2. 193-209.

Sódor Alajos: Matthes Roriczer „Geometria Deutsch”és „Wimpergbüchlein” címủ könyveiről (1486-1490). Épités- Épitészettudomány 14 (1982) 3-4. 373-405.

Strommer László: Történeti boltozati formák geometriai elemzése és ábrázolása a CAD eszközeivel. Doktori disszertáció. BME, Budapest 2008.

Szakál Ernő: Középkori kőfaragó szerkesztések. In: A müemlékhelyreállitás gyakorlata: Az Egri Nyári Egyetem elöadásai, 1977. augusztus 1-10. Egri Nyári Egyetem Intéző Bizottsága, Eger 1978. 95-106.

Szakál Ernő: Köfaragók mühelytitkai. Magyar Köszövetség, Budapst 2007. Szekér György: Demetrius lapicida - Egy pécsi kőfaragó mester az 1500 körüli időkből. Müemlékvédelmi Szemle (1992) 2. 15-24.

Szekér György: Az elméleti rekonstrukció, mint tudományos módszer A diósgyőri vár déli fala fülkeboltozatának kutatása. In: Régészeti Kalandozások 2014. 27-32.

Szőke Balázs: A szeged-alsóvárosi ferences templom hajóboltozata. In: A ferences lelkiség hatása az újkori Közép-Európa történetére és kultúrájára II. PPKE BTK, Piliscsaba 2005. 875-890.

Szőke Balázs: Boltozat-rekonstrukciók és boltozatok számítógépes elemzése. In: Reneszánsz látványtár - Virtuális utazás a múltba. Magyar Nemzeti Múzeum, Budapest 2009. 443-461.

Tompos-Zádor-Sódor 1975 Cs. Tompos Erzsébet - Zádor Mihály - Sódor Alajos: Az épitészet története. Középkor. Tankönyvkiadó, Budapest 1975.

Várnai 1974

Várnai Dezső: Az esztergomi királyi palota építési szakaszai. In: Magyar müemlékvédelem 1971-1972. Akadémiai Kiadó, Budapest 1974. 75-102.

Zádor 1966
Zádor Anna: Henszlmann Imre építészetelmélete és a gótizálás kialakulása. Épités- és Közlekedéstudományi Közlemények 10 (1966) 2. 207-228. 


\title{
TOVÁBBI IRODALOM
}

Dehio, Georg: Ein Proportionsgesetz der antiken Baukunst und sein Nachleben im Mittelalter und in der Renaissance. Strasbourg 1895.

Entz Géza: Gótikus épitészet Magyarországon. Corvina, Budapest 1974.

Hahnloser, Hans R.: Villard de Honnecourt: Kritische Gesamtausgabe des Bauhüttenbuches ms. fr. 19093 der Pariser Nationalbibliothek. Bécs 1935.

Hasak, Max: Die romanische und die gotische Baukunst. Stuttgart 1902.

Haskins, Homer: The Renaissance of the Twelfth Century. Harvard University Press, Cambridge 1927.

Hoffstadt, Friedrich: Gotisches ABC Buch: das ist: Lehrbuch der Grundregeln des gotischen Styls, und insbesondere der gotischen Architektur. Frankfurt 1845.

Istvánfi Gyula: Építészeti szerkesztőmódszerek az ókori Egyiptomban. Épités - Épitészettudomány 42 (2014) 3-4. 159-171.

Koepf, Hans: Die gotischen Plenrisse der wiener Sammlungen. Bécs 1969.

Marosi Ernő: A román kor müvészete. Corvina, Budapest 1972.

Müller, Werner: Das Sterngewölbe des Lorenzer Hallenchores: seine Stellung innerhalb der spätgotischen Gewölbekonstruktionen. In: 500 Jahre Hallenchor St. Lorenz zu Nürnberg 1477-1977. Nürnberg 1977.

Panofsky, Erwin: Gothic Architecture and Scholasticism. Cleveland 1961.

Pevsner, Nikolaus: Az európai épitészet története. Corvina, Budapest 1995.

Ritz Sándor: A templom. Róma 1985.

Ržiha, Franz: Studien über Steinmetzzeichen. Bécs 1883.

Stieglitz, C. L.: Geschichte der Baukunst der Alten. Leipzig 1792.

Ungewitter, G.: Lehrbuch der gotischen Konstruktionen 1. Tauschnitz, Leibzig 1901.

\section{ARCHITECTURAL DESIGN METHODS OF THE MIDDLE AGES BY THE HUNGARIAN HISTORIOGRAPHY}

\begin{abstract}
Summary
Monument preservation and research of architectural history always require a highly sophisticated professional prudence and the consideration of the point of view of several disciplines. Designing and preliminary process of architecture has always been the basic problem of creating a building, therefore its study is to be a considerable part of history of architecture and reconstruction projects as well. In our essay we summarise the geometrical and proportional systems and design methods of medieval architecture. The Hungarian, as well as the international historiography of this subject dates back to the middle of the 19th century. During this more than 150 years the various and undoubtedly progressive aspects of all the relevant disciplines - architecture, history of art, archaeology, sculpture - were represented while they have enriched the research of design methods of medieval buildings. This complex knowledge is to be resumed and systematized so as to reveal the unanswered questions and to refine the direction of the future research. Paying tribute to this scientific tradition, our essay is to collect and analyse the scientific works of this subject without diminishing the importance of experts of other disciplines of medieval studies.
\end{abstract}

Keywords: Middle Ages, geometry, proportion, design, Villard de Honnecourt, Roriczer 